\title{
Genetic architecture and heritability of early-life telomere length in a wild passerine
}

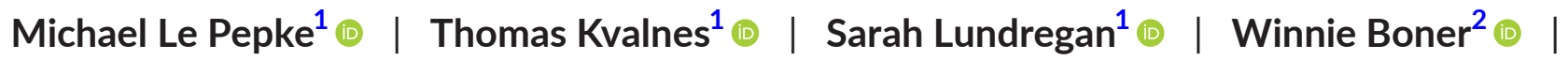

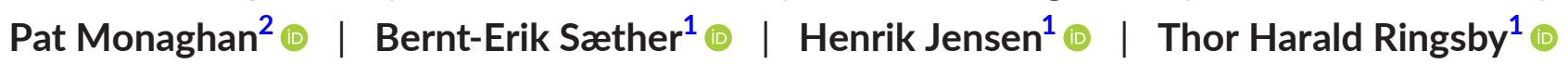

${ }^{1}$ Department of Biology, Centre for Biodiversity Dynamics (CBD), Norwegian University of Science and Technology (NTNU), Trondheim, Norway

${ }^{2}$ Institute of Biodiversity, Animal Health and Comparative Medicine (IBAHCM),

University of Glasgow, Glasgow, UK

\section{Correspondence}

Michael Le Pepke, Department of Biology, Centre for Biodiversity Dynamics (CBD), Norwegian University of Science and Technology (NTNU), Trondheim, Norway. Email: michael@pepke.dk

Funding information Norges Forskningsråd, Grant/Award Number: 223257 and 274930

\begin{abstract}
Early-life telomere length ( $T L$ ) is associated with fitness in a range of organisms. Little is known about the genetic basis of variation in TL in wild animal populations, but to understand the evolutionary and ecological significance of TL it is important to quantify the relative importance of genetic and environmental variation in TL. In this study, we measured TL in 2746 house sparrow nestlings sampled across 20 years and used an animal model to show that there is a small heritable component of early-life $\mathrm{TL}\left(h^{2}=0.04\right)$. Variation in TL among individuals was mainly driven by environmental (annual) variance, but also brood and parental effects. Parent-offspring regressions showed a large maternal inheritance component in $\mathrm{TL}\left(h_{\text {maternal }}^{2}=0.44\right)$, but no paternal inheritance. We did not find evidence for a negative genetic correlation underlying the observed negative phenotypic correlation between TL and structural body size. Thus, TL may evolve independently of body size and the negative phenotypic correlation is likely to be caused by nongenetic environmental effects. We further used genome-wide association analysis to identify genomic regions associated with TL variation. We identified several putative genes underlying TL variation; these have been inferred to be involved in oxidative stress, cellular growth, skeletal development, cell differentiation and tumorigenesis in other species. Together, our results show that TL has a low heritability and is a polygenic trait strongly affected by environmental conditions in a free-living bird.
\end{abstract}

\section{KEYWORDS}

animal model, ecological genetics, genetic correlation, genome-wide association studies, lifehistory, telomere inheritance

\section{1 | INTRODUCTION}

Telomeres are nucleoprotein structures that cap the ends of linear chromosomes in most eukaryotes (Blackburn, 1991). Understanding the causes of individual variation in telomere length $(T L)$ is important because this trait has been shown to predict variation in survival or lifespan within and among species, particularly in birds (Bize et al., 2009; Froy et al., 2021; Heidinger et al., 2012; Joeng et al.,

Henrik Jensen and Thor Harald Ringsby-Joint senior authors.

This is an open access article under the terms of the Creative Commons Attribution License, which permits use, distribution and reproduction in any medium, provided the original work is properly cited.

(C) 2021 The Authors. Molecular Ecology published by John Wiley \& Sons Ltd. 
2004; Monaghan, 2010; Pepke \& Eisenberg, 2021; Tricola et al., 2018; Wilbourn et al., 2018) and individual fitness in wild animals (Eastwood et al., 2019, but see Wood \& Young, 2019). Telomeres shorten through life in many organisms (Dantzer \& Fletcher, 2015; Remot et al., 2021) due to cell division, oxidative stress, and other factors (Jennings et al., 2000; Reichert \& Stier, 2017). This can result in telomere dysfunction, genome instability, cell death (Nassour et al., 2019), and organismal senescence (Herbig et al., 2006). Individual TL or telomere loss may act as biomarkers or sensors of exposure to intrinsic and extrinsic stressors (Bateson, 2016; Houben et al., 2008), and hence reflect individual condition (Rollings et al., 2017), but the physiological mechanisms underlying the ontogenetic variation in TL are not well understood (Erten \& Kokko, 2020; Monaghan, 2014). Several studies have investigated the potential of telomere dynamics (i.e., individual differences in TL and telomere loss rate) in mediating life-history trade-offs both across (Dantzer \& Fletcher, 2015; Pepke \& Eisenberg, 2020) and within relatively long-lived species (Monaghan, 2010; Spurgin et al., 2018). However, despite being an ecologically important trait in many species (Wilbourn et al., 2018), knowledge about the genetic architecture of TL and its adaptive potential in wild populations remains scarce (Dugdale \& Richardson, 2018).

Quantifying the additive genetic variance of a trait is required to understand mechanisms driving adaptive evolution, that is, the response to selection on a trait (Ellegren \& Sheldon, 2008; Kruuk et al., 2008; Lande, 1979). However, the magnitude of the heritability and mode of inheritance of TL is not well-known in populations of wild animals, and few general patterns have been described (Bauch et al. 2019; Dugdale \& Richardson, 2018; Horn et al., 2011). Utilizing longterm pedigree data, individual variation in early-life TL can be decomposed into various genetic and environmental sources of variation through a type of mixed-effect model ("animal model"), which takes all relationships from the pedigree into account (Kruuk, 2004; Wilson et al., 2010). Estimates of TL heritabilities from studies using animal models (reviewed in Dugdale \& Richardson, 2018) have varied considerably across wild bird populations, from $h^{2}=0(n=177$, in whitethroated dippers, Cinclus cinclus, Becker et al., 2015) to $h^{2}=0.74$ ( $n=715$, in western jackdaws, Coloeus monedula, Bauch et al., 2021). While most studies are characterized by relatively small sample sizes, recent long-term studies on Seychelles warblers (Acrocephalus sechellensis, $n=1317, h^{2}=0.03-0.08$, Sparks et al., 2021) and common terns (Sterna hirundo, $n=387, h^{2}=0.46-0.63$, Vedder et al., 2021) also revealed contrasting estimates of TL heritabilities. Epidemiological studies of humans have documented consistently high TL heritabilities, ranging from $h^{2}=0.34-0.82$ (Broer et al., 2013). In humans, some studies reported strong paternal inheritance (e.g., Njajou et al., 2007) or maternal inheritance (e.g., Broer et al., 2013) or that there were no differences in parental mode of inheritance (e.g., Eisenberg, 2014). In birds, several studies have documented maternal effects on offspring telomere dynamics (Asghar et al., 2015; Heidinger et al., 2016; Horn et al., 2011; Reichert et al., 2015), or effects of parental age at conception on offspring TL (Eisenberg \& Kuzawa, 2018; Marasco et al., 2019; Noguera José et al., 2018). Reichert et al. (2015) found a significant correlation between mother-offspring TL measured at 10 days of age in king penguins (Aptenodytes patagonicus), but not when TL was measured at later ages ( $>70$ days). This may be because post-natal telomere loss rate is strongly influenced by individual environmental circumstances (Chatelain et al., 2020; Wilbourn et al., 2018) and does not always correlate strongly with chronological age (Boonekamp et al., 2013, 2014).

Faster growth in early life is associated with reduced longevity (Metcalfe \& Monaghan, 2003) and TL may be involved in mediating the trade-off between growth rate and lifespan (Salmón et al., 2021; Young, 2018). Accordingly, a negative phenotypic correlation between $T L$ and body size or growth rate has been documented within several species (Monaghan \& Ozanne, 2018, but see Boonekamp et al., 2021). Telomeres are known to shorten during growth (Ringsby et al., 2015), but a negative phenotypic correlation may also indicate the existence of a negative genetic correlation (Roff, 1995; Roff \& Fairbairn, 2012). Froy et al. (2021) reported a modest negative genetic correlation $\left(r_{\mathrm{A}}=-0.2\right)$ between bodyweight and TL in feral Soay sheep (Ovis aries). Furthermore, we have previously shown that artificial directional selection on body size in wild house sparrows (Passer domesticus) affected TL in the opposite direction (Pepke et al., 2021). This suggests that there is a genetic correlation between the two traits. Thus, quantifying the genetic correlation between TL and body size enables us to determine whether the two traits can evolve independently of each other or if the pattern of selection on both traits is needed for predicting evolutionary responses (Kruuk et al., 2008).

Telomere length is a complex phenotypic trait (Aviv, 2012; Hansen et al., 2016) expected to be polygenic, that is, affected by small effects of many genes (Dugdale \& Richardson, 2018; Hill, 2010). Accordingly, numerous genome-wide association studies (GWAS), which tests correlative associations of single-nucleotide polymorphisms (SNPs) with specific traits, have identified several loci correlated with TL in humans that map to genes involved in telomere and telomerase maintenance, DNA damage repair, cancer biology, and several nucleotide metabolism pathways (e.g., Andrew et al., 2006; Codd et al., 2010, 2013; Coutts et al., 2019; Deelen et al., 2013; Delgado et al., 2018; Jones et al., 2012; Levy et al., 2010; Li et al., 2020; Liu et al., 2014; Mangino et al., 2012, 2015; Mirabello et al., 2010; Nersisyan et al., 2019; Ojha et al., 2016; Soerensen et al., 2012; Vasa-Nicotera et al., 2005; Zeiger et al., 2018). None of the GWA studies in humans specifically tested the marker associations of early-life TL, which pose a challenge to the interpretation of the results, as TL shortens through life in humans (Blackburn et al., 2015) and genes may have different impacts at various life stages (Weng et al., 2016). Furthermore, large sample sizes and dense sampling of genetic loci is needed to ensure high power in GWA studies (Mackay et al., 2009) and resolve any pleiotropic effects (Prescott et al., 2011). The genes influencing TL in humans that were identified through GWAS only explain a small proportion of the interindividual variation in TL ( $<2 \%$, Aviv, 2012; Codd et al., 2013; Fyhrquist et al., 2013). One GWAS on TL of a nonhuman species (dairy cattle, Bos taurus) was recently performed (Ilska-Warner et al., 2019) supporting the polygenic nature of early-life TL. However, domesticated 
species in captivity may display TL dynamics that are not representative of natural populations (Eisenberg, 2011; Pepke \& Eisenberg, 2021). There are to the best of our knowledge no previous GWAS on TL performed in natural populations.

In this study, we aimed to provide novel insights into the genetic architecture of TL and the evolutionary mechanisms by which natural selection can alter telomere dynamics using data from a passerine bird. We obtained a single measure of TL in individuals ( $n=2746$ ) born within 20 cohorts in two natural insular populations of wild house sparrows at a similar age (c. 10 days), in addition to individuals at the same age in two insular populations that underwent artificial selection on body size for four consecutive years ( $n=569$, Kvalnes et al., 2017; Pepke et al., 2021). First, we estimated the phenotypic correlations between TL and tarsus length (as a proxy for body size, Araya-Ajoy et al., 2019; Senar \& Pascual, 1997) in house sparrow nestlings. Second, we tested for effects of parental age on offspring TL. Third, we estimated heritability, environmental variances, and parental effects on early-life TL, and test for genetic correlations between TL, tarsus length, and body condition in the natural populations (primary analyses). Nestling body condition (body mass corrected for structural body size, Schulte-Hostedde et al., 2005) is included here to account for the component of body size that is not explained by tarsus length, which could be due to variation in the mass of other tissues or fat reserves (Peig \& Green, 2010). We then used similar analyses in the artificially selected populations to validate our results from the primary analyses. Finally, we used highdensity genome-wide single nucleotide polymorphism (SNP) genotype data (Lundregan et al., 2018) in a GWAS to identify genetic regions and potential candidate genes underlying variation in earlylife TL within wild house sparrows (up to $n=383$ ).

\section{2 | MATERIALS AND METHODS}

\section{1 | Study populations and data collection}

The study was performed in four insular house sparrow populations off the coast of northern Norway (Figure S1.1 in Appendix S1). The study periods differed between the populations with data from Hestmannøy $\left(66^{\circ} 33^{\prime} \mathrm{N}, 12^{\circ} 50^{\prime} \mathrm{E}\right)$ in the years $1994-2013$, Træna (Husøy island, $66^{\circ} 30^{\prime} \mathrm{N}, 12^{\circ} 05^{\prime} \mathrm{E}$ ) in the years $2004-2013$, and Leka $\left(65^{\circ} 06^{\prime} \mathrm{N}, 11^{\circ} 38^{\prime} \mathrm{E}\right)$ and Vega $\left(65^{\circ} 40^{\prime} \mathrm{N}, 11^{\circ} 55^{\prime} \mathrm{E}\right)$ both in the years 2002-2006. Hestmannøy and Træna were unmanipulated natural populations and are included in the primary analyses. The populations of Leka and Vega underwent artificial size selection (see Kvalnes et al., 2017; Pepke et al., 2021) and were analysed separately in a set of secondary analyses as replications of the primary analyses. All four islands are characterized by heathland, mountains, and sparse forest. The sparrows live closely associated with humans and within the study area they are found mainly on dairy farms (Hestmannøy, Vega and Leka), where they have access to food and shelter all year, or in gardens and residential areas (Træna), where they may be more exposed to weather conditions (Araya-Ajoy et al., 2019). Natural nests inside barns or artificial nest boxes were visited at least every ninth day during the breeding season (May-August) to sample fledglings (5-14 days old, with a median of 10 days). All individuals were ringed using a unique combination of a metal ring and three plastic colour rings. Fledged juvenile sparrows and unmarked adults were captured using mist nets from May to October. These procedures ensured that approximately $90 \%$ of all adult birds were marked on all islands during the study period (Jensen et al., 2008; Kvalnes et al., 2017). We measured tarsometatarsus (tarsus) length using digital slide calipers to nearest $0.01 \mathrm{~mm}$ and body mass to nearest $0.1 \mathrm{~g}$ with a Pesola spring balance (see Appendix S1). Morphological measurements were taken by different fieldworkers. All fieldworkers were carefully trained to consistently use the same measurement technique of THR or, in some cases, another experienced fieldworker (Kvalnes et al., 2017). For 234 out of 2746 nestlings, no nestling morphological measurements were made. Following Schulte-Hostedde et al. (2005) nestling body condition was calculated as the residuals of a linear regression of mass on tarsus length (both $\log _{10}$-transformed). To avoid collinearity in models where both nestling age and tarsus length were included as covariates, we age-corrected tarsus length by using the residuals from a regression of tarsus length on age and age squared (to account for the diminishing increase in tarsus length with age). One blood sample $(25 \mu \mathrm{l})$ was collected from each fledgling, which was stored in $96 \%$ ethanol at room temperature in the field and subsequently at $-20^{\circ} \mathrm{C}$ in the laboratory until DNA extraction.

\section{2 | Molecular sexing and pedigree construction}

DNA extraction is described in Appendix S1. Sex of most fledglings ( $n=2641$ ) was determined using amplification of the CHD-gene located on the avian sex chromosomes as described in Griffiths et al. (1998). 21 individuals were sexed exclusively based on their phenotype as adults and 84 nestlings could not be sexed. The pedigree construction is detailed in previous studies (Billing et al., 2012; Jensen et al., 2003, 2008; Rønning et al., 2016). Briefly, we used individual genotypes on 13 polymorphic microsatellite markers scored using the GENEMAPPER 4.0 software (Applied Biosystems) to assign parentage in CERVUs 3.0 (Kalinowski et al., 2007). Nestlings within the same clutch were assumed to have the same mother. Nestlings with missing parents (unassigned: $n=662$ with missing mother and $n=700$ with missing father) were assigned dummy parents, assuming that nestlings within the same clutch were full siblings and thus had the same (unassigned) parents. The dummy parents were included in the pedigree as founders. We calculated individual inbreeding coefficients $(F)$ based on the microsatellite pedigree using the R package pedigree (Coster, 2012). Pedigrees were ordered using the $R$ package MasterBayes (Hadfield et al., 2006) and pruned to only contain informative individuals. The pruned pedigrees included 4118 individuals (3093 maternities and 3130 paternities) in the natural populations, and 1057 individuals in artificially selected populations. Maximum pedigree depth was 13 generations, the number of equivalent complete generations (the sum of the proportion of known 
ancestors across all generations, Wellmann, 2021) was 1.510, and mean pairwise relatedness was 0.003 .

\section{3 | Telomere length measurements}

Relative erythrocyte telomere lengths (TL) of 2746 nestlings from Hestmannøy and Træna (sample sizes are detailed in Table S1.1 in Appendix S1) were successfully measured using the real-time quantitative polymerase chain reaction ( $\mathrm{qPCR}$ ) amplification method by Cawthon (2002) with modifications by Criscuolo et al. (2009). Primer sequences, PCR assay setup and thermal profiles followed Pepke et al. (2021) and are detailed in Appendix S1. Briefly, this method measures the ratio of telomere sequence relative to the amount of a nonvariable gene (GAPDH) and a reference sample. The reference sample consisted of pooled DNA from six individuals, which was also included as a two-fold serial dilution (40-2.5 ng/well) on all plates to produce a standard curve, in addition to a nontarget control sample (all in triplicates). Samples were randomized and run on $2 \times 12596$ well plates (telomere and GAPDH assays, respectively). The qPCR data was analysed using the QBASE software (Hellemans et al., 2007), which computes relative $T L$ as the ratio $(T / S)$ of the telomere repeat copy number ( $\mathrm{T}$ ) to a single copy gene number (S) similar to Cawthon (2002). In qBASE the T/S ratio is calculated as calibrated normalized relative quantities (CNRQ) that control for differences in amplification efficiency between plates and for inter-run variation by including three inter-run calibrators from the standard curve. All individual plate efficiencies were within $100 \pm 10 \%$ (mean telomere assay efficiency was $97.5 \pm 3.9 \%$, and $97.6 \pm 4.2 \%$ for GAPDH assays). The average of the reference sample cycle thresholds $(\mathrm{Ct})$ across all plates were $10.54 \pm 0.03$ SD and $21.53 \pm 0.02$ SD for telomere and GAPDH assays, respectively. Thus, while reproducibility of TL measurements within the reference sample of the same DNA sample extract is high, we performed DNA re-extraction of the same blood samples for 25 individuals to test TL consistency across DNA extractions (Appendix S1). The re-extractions were run on different plates and the TL estimates of these samples remained highly correlated $\left(R^{2}=0.75\right.$, Figure S1.3 in Appendix S1). For these individuals, the average of the TL measurements was used in subsequent analyses. All reactions for the primary analyses (from the populations on Hestmannøy and Træna) were performed by the same person (MLP). MLP and WB generated the secondary data set $(n=569$ on $2 \times 21$ plates, from the populations on Leka and Vega) as described in Pepke et al. (2021). The primary and secondary data sets used different reference samples and are therefore not combined in the analyses.

\subsection{Statistical analyses}

\subsection{1 | The correlation between tarsus length and telomere length}

We first tested the phenotypic correlation between TL and tarsus length (as a proxy for body size) within 2462 house sparrow nestlings from Hestmannøy and Træna. TL (response variable) was $\log _{10}$-transformed and linear mixed-effects models (LMMs) were fitted with a Gaussian error distribution ( $R$ package Ime4, Bates et al., 2015). Sex differences in TL are known for house sparrows (Pepke et al., 2021). Thus, models included sex (continuous) fledgling age at sampling, hatch day (numbered day of year mean centred across years), and island identity as fixed effects. We fitted random intercepts for brood identity, year, and qPCR plate identity to account for the non-independence of nestlings from the same brood, year and plate. Because our study populations are known to be affected by inbreeding depression (Niskanen et al., 2020), we included the inbreeding coefficient ( $F$, continuous) as a fixed effect (Reid \& Keller, 2010). We then compared models with and without (age-standardized) tarsus length using Akaike's information criterion corrected for small sample sizes (AICc, Akaike, 1973; Hurvich \& Tsai, 1989), and Akaike weights (w) and evidence ratios (ER) to determine the relative fit of models given the data (Burnham \& Anderson, 2002). Models were validated visually by diagnostic plots and model parameters are from models refitted with restricted maximum likelihood (REML). Estimates and 95\% confidence intervals (CI) are reported.

\subsection{2 | Parental age effects on offspring telomere length}

We tested whether maternal age at conception (MAC [mean $1.8 \pm 1.1$ SD years, range 1-7 years], $n=373$ mothers with $n=1967$ offspring) or paternal age at conception (PAC [mean $2.1 \pm 1.2$ SD years, range 1-8 years], $n=388$ fathers with $n=1927$ offspring) predicted TL in offspring from Hestmannøy and Træna. We applied within-subject centring (van de Pol \& Wright, 2009) to separate within-parental age effects (e.g., senescence) from between-parental age effects (e.g., selective disappearance), by including both the mean parental age at conception and the deviation from the mean parental age for each parent as fixed effects in two LMMs (for fathers and mothers, respectively) explaining variation in offspring $T L\left(\log _{10}\right.$-transformed). Both models included island identity and sampling age as fixed effects, and random intercepts for year, qPCR plate identity, and either maternal identity or paternal identity.

\subsubsection{Heritabilities and genetic correlation of telomere length, tarsus length, and body condition}

We used a multivariate Bayesian animal model (Hadfield, 2019; Kruuk, 2004) fitted with Markov chain Monte Carlo (MCMC) to estimate heritability and genetic correlations of early-life $T L$, agestandardized tarsus length and body condition in the two natural island populations (Hestmannøy and Træna, $n=2662$ ) and the two manipulated island populations (Leka \& Vega, $n=569$ ) that underwent artificial size selection. TL was $\log _{10}$-transformed and all traits were fitted with a Gaussian error distribution using the R package 
MCMCgImm (Hadfield, 2010). Models included sex, fledgling age at sampling (associated only with TL and condition), island identity, and inbreeding coefficient (F) as fixed effects (Wilson, 2008), which were fitted such that different regression slopes were estimated for each trait (Hadfield, 2019). To estimate variance components, random intercepts were included for individual identity linked to the pedigree ("animal", $V_{A}$ ), brood identity $\left(V_{B}\right)$ nested under mother identity, father $\left(V_{F}\right)$ and mother identity $\left(V_{M}\right)$, and birth year (cohort effects, $V_{Y}$ ). Parental effects include those influences on offspring TL that are repeatable across the lifetime of the mother or father (Kruuk \& Hadfield, 2007), while brood identity accounts for other common environmental effects (McAdam et al., 2014). House sparrows are multibrooded laying up to three clutches in a season and may breed in multiple years, with an average of $3.6 \pm 1.3$ SD fledglings per brood in this study. Furthermore, to account for variance associated with measurement error we included qPCR plate identity $\left(V_{O}\right.$, associated only with TL, see e.g., Froy et al., 2021; Sparks et al., 2021). Random effects were generally specified with $3 \times 3$ covariance matrices to estimate the variances and covariances between the effects for each trait. We used inverse-Wishart priors for random effects and residual variances in the multivariate model ( $V=I_{3}$ and $n u=3$, Hadfield, 2019). We reran analyses with other relevant priors (parameter expanded) to verify that results were not too sensitive to the choice of prior. The MCMC chain was run for 2,000,000 iterations, sampling every 500 iterations after a burnin of $5 \%(100,000$ iterations). Mixing and stationarity of the MCMC chain was checked visually and using Heidelberger and Welch's convergence test (Heidelberger \& Welch, 1983) implemented in the "coda" package (Plummer et al., 2006). All autocorrelation values were $<0.1$ and effective sample sizes were $>3000$. The narrowsense heritability was calculated as the posterior mode of the proportion of phenotypic variance $\left(V_{p}\right)$ explained by additive genetic variance (Wilson et al., 2010): $h^{2}=\frac{V_{A}}{V_{A}+V_{B}+V_{F}+V_{M}+V_{Y}+V_{O}+V_{R}}$, where $V_{R}$ is the residual variance. We also estimated heritabilities excluding $V_{O}$ from the total phenotypic variance since it does not represent biological variance (de Villemereuil et al., 2018). Estimates are provided as their posterior mode with $95 \%$ highest posterior density intervals (HPD). All analyses were performed in R version 3.6.3 (R Core Team, 2020).

We also ran univariate models of TL, tarsus length and body condition including the same fixed and random effects as in the multivariate model (Appendix S2). For comparison with previous studies (e.g., Asghar et al., 2015), we tested whether maternal TL and/or paternal TL predicted offspring TL using two LMMs (parent-offspring regressions, Appendix S2). Parental heritabilities ( $h_{\text {maternal }}^{2}$ and $\left.h_{\text {paternal }}^{2}\right)$ can be estimated from parent-offspring regressions as the slope multiplied by two (one sex contributes half of the genes to their offspring). We used the R package pedantics (Morrissey \& Wilson, 2010) to show that, based on parent-offspring regression, the pruned pedigree of the natural populations had $\geq 80 \%$ power to detect heritabilities $\geq 0.21$ (see Figure S1.2 and Appendix S1). Furthermore, we estimated maternal $\left(V_{\text {DAM }}\right)$ and paternal $\left(V_{\text {SIRE }}\right)$ genetic effects (e.g., Wolf \& Wade, 2016) in a multivariate animal model by fitting random intercepts for maternal and paternal identity linked to the pedigree to quantify these effects while accounting for the environmental variances specified above (Appendix S2). Maternal and paternal heritabilities were calculated as: $h_{\text {maternal }}^{2}=\frac{V_{D A M}}{V_{P}}$ and $h_{\text {paternal }}^{2}=\frac{V_{\text {SIRE }}}{V_{P}}$, respectively (Wilson et al., 2005). To test for sex-specific heritabilities (e.g., Jensen et al., 2003; Olsson et al., 2011), we ran a bivariate animal model of TL in females and males as two different phenotypic traits with a genetic correlation between them (Appendix S2).

\subsection{4 | SNP genotype data and association analyses}

Nestlings that survived to adulthood (recruited) on Hestmannøy and Træna were genotyped on a high-density $200 \mathrm{~K}$ SNP array (detailed in Lundregan et al., 2018) with median distances between SNPs shorter than $5000 \mathrm{bp}$. SNPs were originally identified from whole-genome resequencing of 33 individual house sparrows which were mapped to the house sparrow reference genome (Elgvin et al., 2017). DNA was extracted as described in Hagen et al. (2013), separately from telomere analyses. Data preparation and quality checks were performed using the GenABEL package (GenABEL project developers, 2013). We removed SNPs or individuals for which there was more than $5 \%$ missing data, the minor allele frequency (MAF) was less than $1 \%$, or pairwise identity-bystate (IBS) was more than 95\%. After quality control, the genomic relationship matrix (GRM) was computed based on 180,650 $(180,666)$ autosomal markers in 373 (383) individuals (142 [145] males and 137 [142] females from Hestmannøy and 47 [48] males and 47 [48] females from Træna) with numbers in brackets showing sample sizes when individuals with missing tarsus length measurements are included. We then performed two GWA analyses by fitting LMMs for the variation in TL using the package RepeatABEL (Rönnegård et al., 2016): The first model included age-standardized tarsus length as a covariate, and the second model did not. Both models included sex, age, hatch day (mean centred), $F$, and island identity as fixed effects, and brood identity, year, qPCR plate, and the GRM fitted as random effects. We estimated the proportion of phenotypic variance explained by each SNP as: $h_{\mathrm{SNP}}^{2}=\frac{2 p q \beta^{2}}{V_{\mathrm{P}}}$, where $p$ and $q$ are the allele frequencies and $\beta$ is the estimated allele substitution effect (Falconer \& Mackay, 1996). Finally, we determined if SNPs significantly associated with TL were within $100 \mathrm{~kb}$ of any gene within the annotated house sparrow genome, because this is the distance that linkage disequilibrium decays to background levels in this species (Elgvin et al., 2017; Hagen et al., 2020). Gene ontology (GO) searches were performed using the gene ontology annotation (GOA) database (Binns et al., 2009; Huntley et al., 2015) to obtain an overview of biological processes and molecular functions known to be influenced by the genes. 


\section{$3 \mid$ RESULTS}

\subsection{The correlation between tarsus length and telomere length}

The model explaining variation in TL that included tarsus length was ranked higher than the model without tarsus length $(\triangle \mathrm{AICc}=2.5$, $\left.w_{1}=0.78, E R_{1}=w_{1} / w_{2}=3.55\right)$. There was a negative association between tarsus length and $\mathrm{TL}\left(\beta_{\text {tarsus length }}=-0.004 \pm 0.002, \mathrm{Cl}=[-\right.$ 0.007, -0.000], $n=2462$, Figure 1 and Table 1), such that larger nestlings generally had slightly shorter early-life telomeres. Thus, an increase in (age-corrected) tarsus length of $1 \mathrm{~mm}$ was associated with a decrease in TL of $0.8 \%$.

\section{2 | Parental age effects on offspring telomere length}

There was no evidence for associations between offspring TL and $\operatorname{MAC}\left(\beta_{\triangle \mathrm{MAC}}=0.001 \pm 0.004, \mathrm{Cl}=[-0.007,0.009], \beta_{\text {mean MAC }}=0.001\right.$ $0.005, \mathrm{Cl}=[-0.008,0.010]$, Figures S2.1a,c in Appendix S2) or PAC $\left(\beta_{\triangle \mathrm{PAC}}=0.0050 .003, \mathrm{Cl}=[-0.002,0.011], \beta_{\text {mean PAC }}=-0.001 \pm 0.003\right.$, $\mathrm{Cl}=[-0.008,0.005]$, Figure S2.1b,d in Appendix S2).

\subsection{Heritabilities and genetic correlations of telomere length, tarsus length, and body condition}

We found nonzero additive genetic variances $\left(V_{A}\right)$ for $\operatorname{TL}\left(V_{A}=0.009\right.$, $\mathrm{HPD}=[0.008,0.010])$, tarsus length $\left(V_{\mathrm{A}}=0.201, \mathrm{HPD}=[0.111\right.$, $0.314])$ and body condition $\left(V_{A}=0.006, H P D=[0.005,0.006]\right)$ in the natural populations (Table 2, Figure 2). The main component contributing to variance in TL was between-year differences $\left(V_{Y}\right.$, explaining $68 \%$ of the total variance), while maternal $\left(V_{M}, 7 \%\right)$, paternal $\left(V_{F}, 7 \%\right)$, brood $\left(V_{B}, 6 \%\right)$, and $q P C R$ plate variances $\left(V_{O}, 5 \%\right)$ also explained considerable proportions of the total phenotypic variance (Figure 2). Combined, the environmental effects captured $87 \%$ of the phenotypic variance in TL. Variation in TL measurements across years is shown in Figure S2.2: Appendix S2. For tarsus length and condition, the main variance components were among different broods (38\%) and among years (76\%), respectively (Table 2 , Figure 2). The heritabilities were $h^{2}=0.039$ for TL (HPD $=[0.022$, $0.057]), h^{2}=0.080$ (HPD $=[0.045,0.124]$ ) for tarsus length, and $h^{2}=0.027$ (HPD $\left.=[0.015,0.043]\right)$ for body condition. Heritability for TL increased slightly to $h^{2}=0.041$ (HPD $=[0.023,0.061]$ ) when excluding $\mathrm{qPCR}$ plate variance $\left(V_{\mathrm{O}}\right)$ from the total phenotypic variance (Table 2). The heritability estimates were of the same magnitude in the univariate animal models (Table S2.1 in Appendix S2). There was no evidence for a genetic correlation between TL and tarsus length $\left(r_{\mathrm{A}}=-0.029, \mathrm{HPD}=[-0.120,0.078]\right)$ or between $\mathrm{TL}$ and condition $\left(r_{\mathrm{A}}=-0.011, \mathrm{HPD}=[-0.080,0.055]\right)$.

Parent-offspring regressions showed a large maternal inheritance component in $\mathrm{TL}\left(h_{\text {maternal }}^{2}=0.435 \pm 0.156, \mathrm{Cl}=[0.127,0.741]\right)$, but no paternal inheritance (Figure S2.3 in Appendix S2). Including parental genetic effects in a multivariate animal model confirmed slightly higher maternal $\left(h_{\text {maternal }}^{2}=0.078, \mathrm{HPD}=[0.048,0.099]\right)$ than paternal heritability of TL $\left(h_{\text {paternal }}^{2}=0.072, \mathrm{HPD}=[0.043,0.089]\right.$, Table S2.2 in Appendix S2). We found no evidence of differences in sex-specific heritabilities of TL (Table S2.3 in Appendix S2).

In the analyses of the artificially selected populations (Leka and Vega, Table S2.4 in Appendix S2) we found comparable heritability estimates for TL $\left(h^{2}=0.031, \mathrm{HPD}=[0.005,0.061]\right)$ and body condition $\left(h^{2}=0.018, \mathrm{HPD}=[0.004,0.049]\right)$, and a slightly higher estimate for tarsus length $\left(h^{2}=0.126, \mathrm{HPD}=[0.040,0.237]\right)$. Similarly, there was no evidence for genetic correlations between TL and tarsus $\left(r_{\mathrm{A}}=-0.036, \mathrm{HPD}=[-0.224,0.149]\right)$ or between TL and body condition $\left(r_{\mathrm{A}}=-0.008, \mathrm{HPD}=[-0.129,0.140]\right.$, Table S2.4 in Appendix S2).

\section{4 $\quad$ GWA analyses}

When controlling for the phenotypic effect of tarsus length on TL, nine SNPs showed evidence for an association with early-life TL (Table 3, Figure 3), with a Bonferroni (1935) corrected threshold of $p \leq 2.77 \times 10^{-7}$ at the genome-wide $p$-value threshold (i.e., the nominal $p=.05$ divided by 180,650 markers) and a genomic inflation
FIGURE 1 The negative association between age-corrected tarsus length and telomere length ( $\log _{10}$-transformed) in 2462 house sparrow nestlings with a regression line from a LMM shown in Table 1. The 95\% confidence interval (grey) reflects only the fixed effects

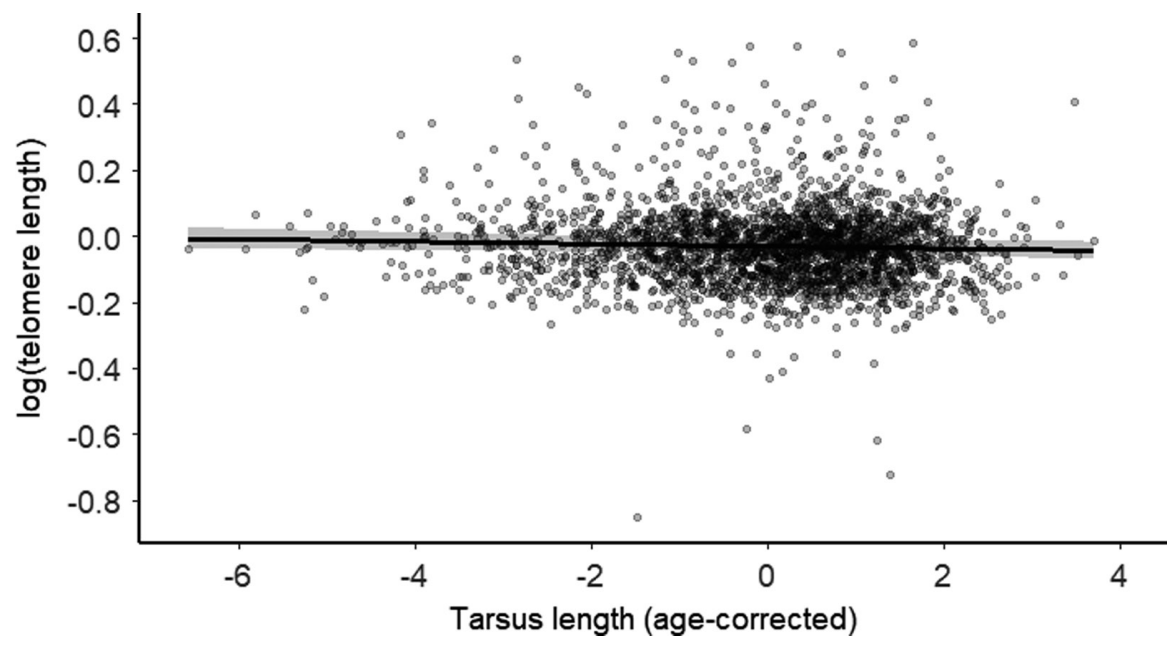




\begin{tabular}{|c|c|c|c|c|c|}
\hline $\begin{array}{l}\text { Response variable: } \\
\log _{10}(T L)\end{array}$ & Estimate & SE & Lower Cl & Upper Cl & $10^{\text {estimate }}$ \\
\hline Intercept & -0.0089 & 0.0202 & -0.0484 & 0.0305 & 0.9797 \\
\hline Tarsus length & -0.0035 & 0.0016 & -0.0066 & -0.0003 & 0.9920 \\
\hline Sex (female) & -0.0042 & 0.0039 & -0.0119 & 0.0035 & 0.9904 \\
\hline $\begin{array}{l}\text { Island identity } \\
\text { (Hestmannøy) }\end{array}$ & -0.0080 & 0.0085 & -0.0250 & 0.0089 & 0.9817 \\
\hline Age & -0.0013 & 0.0015 & -0.0043 & 0.0016 & 0.9970 \\
\hline $\begin{array}{l}\text { Inbreeding coefficient } \\
\quad(F)\end{array}$ & -0.1796 & 0.0941 & -0.3638 & 0.0049 & 0.6613 \\
\hline Hatch day & -0.0001 & 0.0001 & -0.0004 & 0.0001 & 0.9998 \\
\hline$\sigma_{\text {brood ID }}^{2}(n=948)$ & 0.0038 & & 0.0030 & 0.0045 & 1.0088 \\
\hline$\sigma_{\mathrm{qPCR} \text { plate ID }}^{2}(n=125)$ & 0.0010 & & 0.0007 & 0.0015 & 1.0023 \\
\hline$\sigma_{\text {year }}^{2}(n=20)$ & 0.0020 & & 0.0010 & 0.0040 & 1.0046 \\
\hline$\sigma_{\text {residual }}^{2}$ & 0.0071 & & 0.0066 & 0.0077 & 1.0165 \\
\hline \multicolumn{6}{|c|}{ Marginal $R^{2} /$ Conditional $R^{2}: 0.006 / 0.486$} \\
\hline
\end{tabular}

TABLE 1 Estimates, standard errors (SE), lower and upper 95\% confidence intervals $(\mathrm{Cl})$ from a $\mathrm{LMM}$ of variation in telomere length (TL, $n=2462)$

Note: The model included random intercepts for brood identity, qPCR plate identity, and year. Italics indicate parameters with $\mathrm{Cls}$ not overlapping zero.

factor of $\lambda=1.0489 \pm 0.0002$ (Figure S2.3 in Appendix S2). Using the annotated house sparrow genome, a total of 22 genes on five chromosomes were found to be located within proximity $( \pm$ $100 \mathrm{~kb}$ ) of six of the top SNPs (Table 4). Four SNPs that showed weak evidence for an association with TL (nominal .05 $<p<.10$ ) are also shown in Table 3. Among three of these SNPs we identified three genes within $\pm 100 \mathrm{~kb}$ on three chromosomes (Table S2.5 in Appendix S2).

SNPa429690 is located on chromosome 2 within the Aquaporin-1 (AQP1) gene, which encodes the AQP1 water channel membrane protein. The AQP1 protein is abundant in erythrocytes (where TL is measured) and important in regulating body water transport and balance (Nielsen et al., 2002), but also in a range of other physiological functions including cell migration, wound healing, fat metabolism and oxidative stress (Saadoun et al., 2005; Verkman et al., 2014). The same SNP is located $39 \mathrm{~kb}$ from the growth hormone-releasing hormone receptor (GHRHR), which controls body growth (Mullis, 2005), and has been associated with telomerase activity (Banks et al., 2010), lifespan (Soerensen et al., 2012) and the progression of several types of cancer (Chu et al., 2016; Schally et al., 2018; Villanova et al., 2019). Humans with overexpression of growth hormones and consequently insulin-like growth factor 1 (IGF-1) have shorter telomeres (Aulinas et al., 2013; Deelen et al., 2013; Matsumoto et al., 2015; Monaghan \& Ozanne, 2018). SNPa17235 was close (11 kb) to FRMD4B (FERM domain-containing protein $4 \mathrm{~B}$ ), which is involved in epithelial cell polarity that is important in tissue morphogenesis (Ikenouchi \& Umeda, 2010). This SNP was also near other genes related to cell proliferation (UBA3 and TMF1), skeletal muscle organization (LMOD3) and oxidative stress (ARL6IP5, see Table 4). SNPa450086 was 76 kb from OXR1 (oxidation resistance protein 1) that regulates expression of several antioxidant enzymes (Volkert et al., 2000). SNPa108592 was in the vicinity (43-84 kb) of several genes on chromosome 15 linked to cell proliferation, ubiquitination and immune response
(Table 4). SNPi16410 was closest to SHCBP1 (70 kb) and CDCA4 (76 kb), which are both involved in cell proliferation and probably apoptosis (Asano et al., 2014; Wang et al., 2008; Xu et al., 2018; Zou et al., 2019). SHCBP1 is upregulated by growth factor stimulation (Schmandt et al., 1999). CDCA4 is likely involved in the regulation of hematopoietic stem cells from where erythrocytes (reflecting $T L$ ) are derived (Abdullah et al., 2001). Expression of the SCN4A gene (68 kb from SNPa491204) has previously been correlated with TL in human stem cells (Wang et al., 2017). SNPa491204 was $49 \mathrm{~kb}$ from the growth hormone gene $\mathrm{GH}$ (which is linked to TL as mentioned above, see also Pauliny et al., 2015) and WNT9B (40 kb) of the Wnt/ $\beta$-catenin signalling pathway, which is modulated by telomerase (Park et al., 2009). In Appendix S2 we mention interesting genes found beyond the $\pm 100 \mathrm{~kb}$ limits of the top SNPs.

When not controlling for the effect of tarsus length on TL, the same top SNPs were identified as in the analysis above where tarsus length was included (Table S2.6 in Appendix S2). In addition, SNPa208275 was associated with TL and found $47 \mathrm{~kb}$ from FGFR2 encoding a tyrosine-protein kinase that is a receptor for fibroblast growth factors that regulates several aspects of cell proliferation and bone morphogenesis (Table S2.7 in Appendix S2, Katoh, 2009).

\section{4 | DISCUSSION}

The evolutionary response to selection on TL depends on the additive genetic variance of TL and the strength and sign of any genetic correlations with other traits under selection (Lande \& Arnold, 1983). Dugdale and Richardson (2018) criticized past quantitative genetic studies of TL on the main grounds that (1) they applied basic regression analyses that did not consider environmental effects impacting $T L$ and as a consequence of that, additive genetic effects may have been overestimated in previous studies; (2) TL changes 
TAB LE 2 Posterior modes and lower and upper 95\% highest posterior density intervals (HPD) for fixed effects, variance components, and heritability estimates from a multivariate animal model of the covariation of early-life telomere length, age-corrected tarsus length, and body condition $(n=2662)$

\begin{tabular}{|c|c|c|c|c|c|c|c|c|c|}
\hline $\begin{array}{l}\text { Variable } \\
\text { Fixed effects }\end{array}$ & \multicolumn{3}{|c|}{$\log _{10}$ (telomere length) } & \multicolumn{3}{|c|}{ Tarsus length } & \multicolumn{3}{|c|}{ Body condition } \\
\hline Intercept & 0.0217 & -0.1498 & 0.2351 & -0.0119 & -0.3388 & 0.2948 & 0.0034 & -0.1759 & 0.2005 \\
\hline Sex (female) & -0.0039 & -0.0129 & 0.0075 & -0.0662 & -0.1525 & 0.0315 & 0.0012 & -0.0069 & 0.0105 \\
\hline Age & -0.0046 & -0.0093 & -0.0003 & - & - & - & -0.0007 & -0.0063 & 0.0039 \\
\hline \multicolumn{10}{|l|}{ Variance components } \\
\hline$h^{2}$ & 0.0387 & 0.0220 & 0.0565 & 0.0797 & 0.0454 & 0.1239 & 0.0274 & 0.0151 & 0.0427 \\
\hline$h^{2}\left(\right.$ excl. $\left.V_{0}\right)$ & 0.0407 & 0.0227 & 0.0606 & - & - & - & - & - & - \\
\hline$V_{F}$ & 0.0134 & 0.0115 & 0.0153 & 0.1367 & 0.0934 & 0.2121 & 0.0108 & 0.0094 & 0.0123 \\
\hline$V_{Y}$ & 0.1406 & 0.0747 & 0.2840 & 0.2132 & 0.1182 & 0.4777 & 0.1387 & 0.0821 & 0.2930 \\
\hline$v_{\mathrm{O}}$ & 0.0103 & 0.0082 & 0.0137 & - & - & - & - & - & - \\
\hline$V_{R}$ & 0.0068 & 0.0062 & 0.0075 & 0.8174 & 0.7329 & 0.9050 & 0.0043 & 0.0039 & 0.0047 \\
\hline $\begin{array}{l}\text { Covariances between TL and } \\
\text { tarsus }\end{array}$ & & & & \multicolumn{6}{|c|}{$\begin{array}{l}\text { Covariances between TL and } \\
\text { condition }\end{array}$} \\
\hline$r_{\mathrm{A}}$ & -0.0293 & -0.1204 & 0.0779 & $r_{\mathrm{A}}$ & & & -0.0113 & -0.0802 & 0.0554 \\
\hline $\operatorname{Cov}_{\mathrm{A}}$ & -0.0012 & -0.0055 & 0.0031 & $\mathrm{Cov}_{\mathrm{A}}$ & & & -0.0001 & -0.0005 & 0.0004 \\
\hline $\operatorname{Cov}_{B}$ & -0.0033 & -0.0145 & 0.0086 & $\operatorname{Cov}_{B}$ & & & 0.0000 & -0.0010 & 0.0009 \\
\hline
\end{tabular}

Note: Abbreviations refer to: heritability $h^{2}$, additive genetic variance $V_{A}$, brood variance $V_{B}$, maternal variance $V_{M}$, paternal variance $V_{F}$, year variance $V_{Y}, q P C R$ plate variance $V_{O}$, residual variance $V_{R}$, and with identical subscripts for the covariances (Cov) including the additive genetic correlation $r_{A}$.

FIGURE 2 Variance components for TL, tarsus length and body condition visualized as relative proportions of the total phenotypic variance. Abbreviations refer to: additive genetic variance $V_{A}$, brood variance $V_{B}$, paternal variance $V_{F}$, maternal variance $V_{M}, q P C R$ plate variance $V_{O}$, residual variance $V_{R}$, and year variance $V_{Y}$

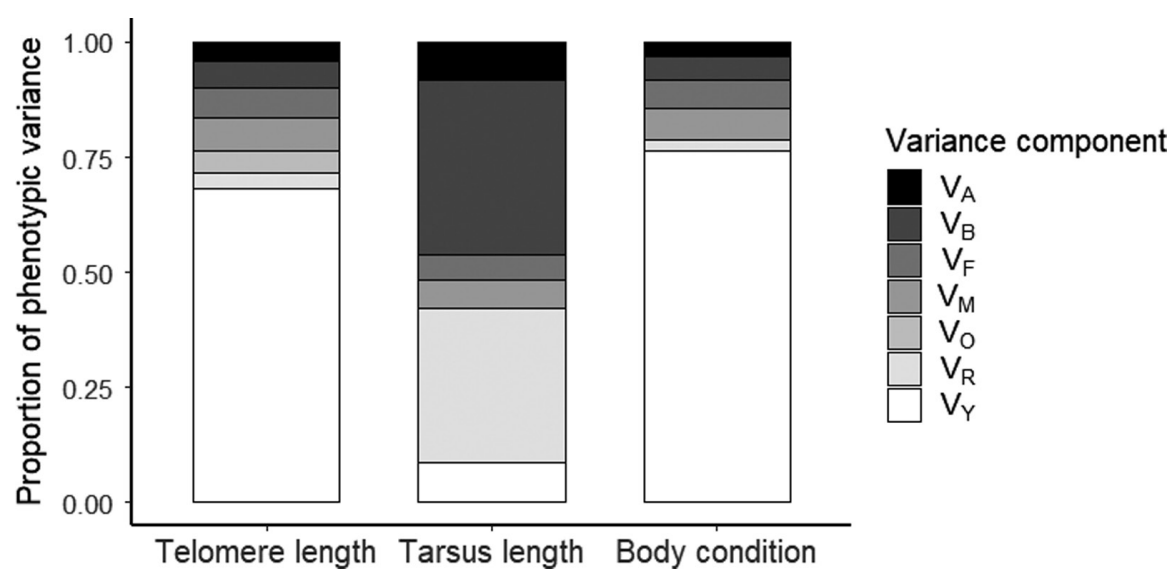

with age, complicating the fact that parents and offspring are often sampled at different ages; and 3) sample sizes were too small to provide enough power to separate genetic and environmental effects using animal models. Here, we have accommodated this critique by (1) using mixed-effect animal models to partition genetic and environmental effects; (2) measuring early-life TL in both 
TAB LE 3 Single nucleotide polymorphisms (SNPs) with evidence (italics) or weak evidence for an association with early-life telomere length in house sparrows $(n=373)$. Chromosome number, SNP position, reference allele A1, effect allele A2, estimated effect size $(\beta)$ with standard error (SE), $p$-value, and Bonferroni adjusted $p$-value are shown

\begin{tabular}{|c|c|c|c|c|c|c|c|c|c|}
\hline SNP & Chromosome & Position & A1 & A2 & $\beta$ & SE & $p$-value & $\begin{array}{l}\text { Adjusted } \\
p \text {-value }\end{array}$ & $h_{S N P}^{2}$ \\
\hline SNPa223513 & 3 & 46984591 & $T$ & C & 0.5770 & 0.0855 & $1.46 E-11$ & $2.63 E-06$ & 0.0438 \\
\hline SNPa500415 & 30 & 133629 & $C$ & $T$ & 0.2919 & 0.0475 & $8.20 E-10$ & 0.0001 & 0.0471 \\
\hline SNPa429690 & 2 & 145079103 & G & $A$ & 0.3627 & 0.0636 & $1.15 E-08$ & 0.0021 & 0.0391 \\
\hline SNPa108592 & 15 & 11173875 & G & $T$ & 0.3409 & 0.0632 & $6.73 E-08$ & 0.0122 & 0.0302 \\
\hline SNPi16410 & 5 & 53016672 & $G$ & $A$ & 0.2242 & 0.0433 & $2.22 E-07$ & 0.0401 & 0.0312 \\
\hline SNPa392732 & 2 & 13674493 & $A$ & G & 0.5017 & 0.0971 & $2.40 E-07$ & 0.0433 & 0.0266 \\
\hline SNPa491204 & 27 & 1191908 & $T$ & C & 0.1387 & 0.0269 & $2.64 E-07$ & 0.0478 & 0.0205 \\
\hline SNPa374949 & 1 & 33502667 & $\mathrm{C}$ & $\mathrm{T}$ & 0.2175 & 0.0428 & 3.84E-07 & 0.0694 & 0.0267 \\
\hline
\end{tabular}

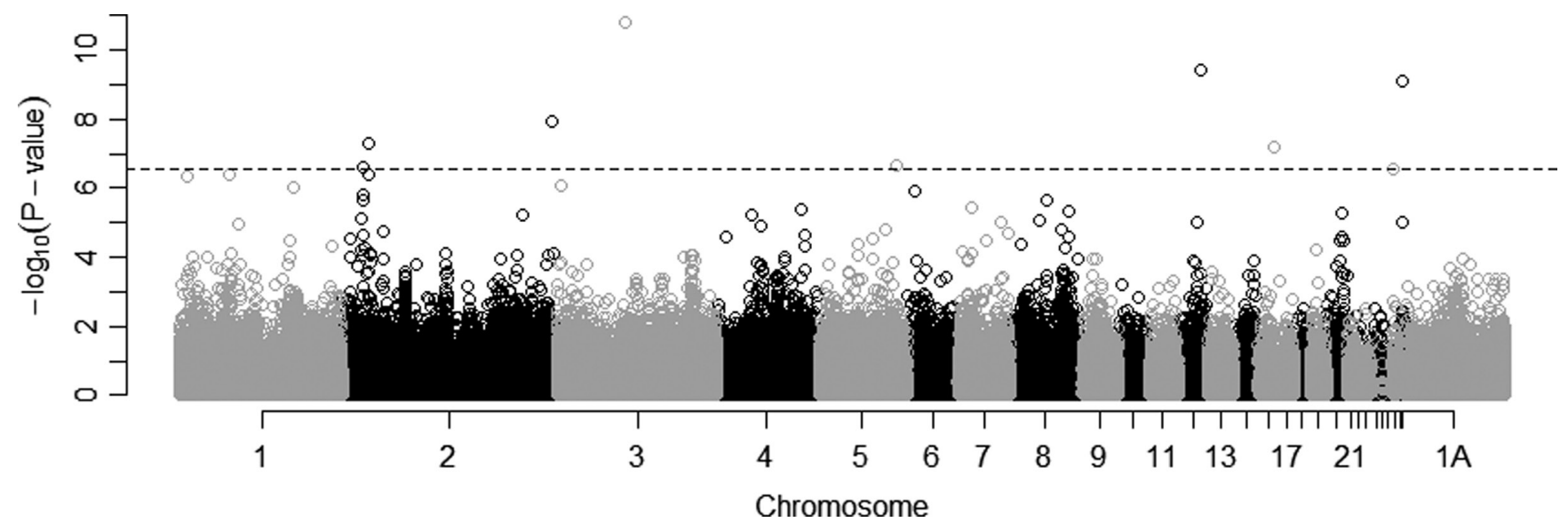

FIGURE 3 Manhattan plot showing genomic location plotted against - $\log _{10}$ ( $p$-value) of the GWA analysis results for early-life telomere length in house sparrows $(n=373)$. The dotted line indicates the genome-wide significance threshold (corresponding to $p<.05$ divided by the number of tests $n=180,650$ SNPs) used to determine the top SNPs listed in Table 3

offspring and parents at the same time point in life (as fledglings); and (3) collecting TL data from more than 3300 individuals across four populations, which represent a considerably larger sample size than those of previous wild animal studies.

We found that around $4 \%$ of the variation in early-life TL in house sparrows at the end of the nestling growth period was determined by additive genetic variation. The relatively small additive genetic variance and large year variance in early-life TL appears to be in accordance with the effects of relative growth and weather conditions on TL in similar sparrow populations (Pepke et al., 2021). The lack of repeated individual TL sampling in this study may prevent us from fully separating between permanent environmental effects and the common environmental effects (brood effects and parental effects, Wilson et al., 2010). However, with several offspring measures for each brood, mother, and father, most of any permanent environmental variance would be included in the residual variance (Kruuk \& Hadfield, 2007). In addition, recent longitudinal studies have found negligible permanent environmental effects on TL (Froy et al., 2021; van Lieshout et al., 2021; Seeker et al., 2018; Sparks et al., 2021; Vedder et al., 2021).

Similarly small but significant heritabilities of TL have been reported using animal models for example, nestling collared flycatchers, Ficedula albicollis ( $h^{2}=0.09$, Voillemot et al., 2012), Seychelles warblers $\left(h^{2}=0.03-0.08\right.$, Sparks et al., 2021) and adult greater mouse-eared bats, Myotis myotis ( $h^{2}=0.01-0.06$, Foley et al., 2020), in which TL correlates with several weather variables. These studies also documented considerable year or cohort effects on TL (Foley et al., 2020; Sparks et al., 2021) similar to studies finding no heritability of TL in white-throated dippers (Becker et al., 2015) and European badgers (Meles meles, van Lieshout et al., 2021). In 


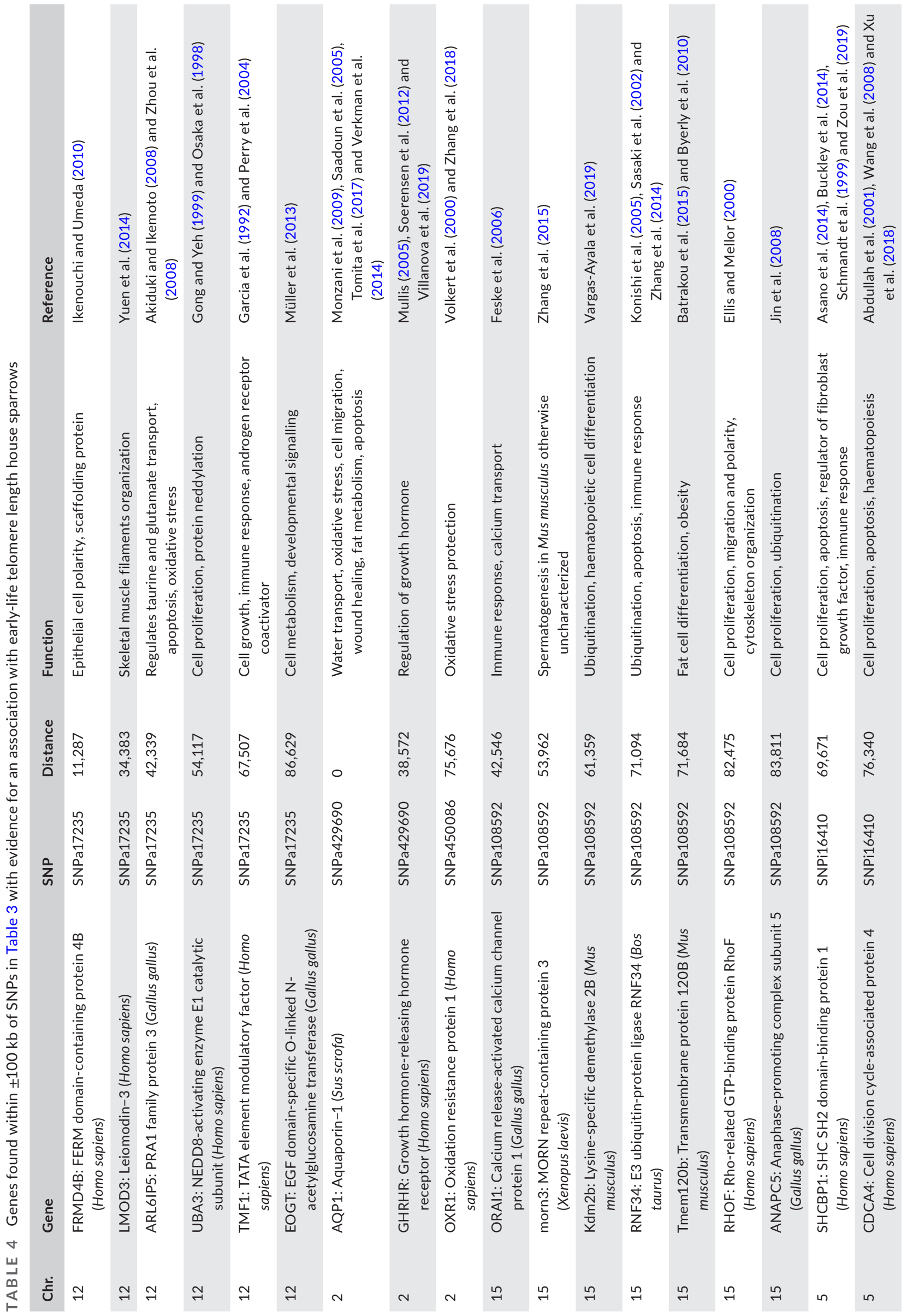


comparison, studies based on parent-offspring regression have often found higher TL heritabilities in e.g. king penguins $\left(h^{2}=0.2\right.$, Reichert et al., 2015), jackdaws (Coloeus monedula, $h^{2}=0.72$, Bauch et al., 2019), and sand lizards (Lacerta agilis, $h^{2}=0.5-1.2$, Olsson et al., 2011). The heritability of TL in house sparrows is comparable to that of many life-history traits and considerably lower than many morphological traits (e.g., Mousseau \& Roff, 1987; Visscher et al., 2008), which may suggest that TL is under strong selection in the wild (Voillemot et al., 2012) or that there are considerable nonadditive genetic or environmental influences on early-life TL. However, recent animal model studies on common terns $\left(h^{2}=0.5\right.$, Vedder et al., 2021) and Soay sheep $\left(h^{2}=0.2\right.$, Froy et al., 2021) found high TL heritabilities and a modest positive genetic correlation (i.e., with Cls overlapping zero) between $T L$ and lifespan $\left(r_{\mathrm{A}}=0.4\right.$ and $r_{\mathrm{A}}=0.3$, respectively). The causes of the variable $T L$ heritability estimates found across wild animal populations, particularly in birds, remain unknown. Curiously, Pepke et al. (2021) reported indications of weak nonlinear or negative associations between TL and various measures of fitness (survival and reproductive success) in house sparrows, suggesting that the environmentally pliant TL dynamics of these relatively fast-lived birds may be very different from several other bird species (reviewed in Wilbourn et al., 2018). In other species, positive associations between early-life TL and survival have been documented (Wilbourn et al., 2018), which may translate into an increased lifetime reproductive success (Bichet et al., 2020; Eastwood et al., 2019; Sudyka, 2019).

A considerable proportion of the phenotypic variance in TL could be attributed to brood and parental effects (Figure 2). However, we did not find evidence that parental effects were transmitted through a parental age at conception effect (Figure S2.1 in Appendix S2). Paternal age effects, which has been observed in several other species (Eisenberg \& Kuzawa, 2018), may not manifest in these house sparrows because the mean age at reproduction in this study was low (around 2 years). Parent-offspring regressions (Figure S2.2 in Appendix S2) suggested a stronger component of maternal heritability $\left(h_{\text {maternal }}^{2}=0.44\right)$ rather than paternal heritability of TL. Maternal heritability estimates from parent-offspring regressions includes both direct additive genetic, maternal genetic and maternal environmental effects (Wilson et al., 2005), and we found a lower maternal heritability $\left(h_{\text {maternal }}^{2}=0.078\right.$ ) when using the animal models (Table S2.2 in Appendix S2). Maternal inheritance of TL has been found in several bird species (Asghar et al., 2015; Becker et al., 2015; Horn et al., 2011; Reichert et al., 2015) and in some studies on humans (Broer et al., 2013), where this has been attributed to an X-linked gene (Nawrot et al., 2004) or implied genomic imprinting (Reichert et al., 2015). In our study, we did not detect sex differences in TL heritability (Table S2.3 in Appendix S2). However, we would expect higher heritability for the sex in which TL is less strongly associated with fitness given similar genetic architectures (Merilä \& Sheldon, 1999; Roff, 2012). Such an association with fitness was found by Heidinger et al. (2021), where early-life TL was positively related to lifetime reproductive success in house sparrows, but only in females. Maternal effects on offspring TL are expected to be strongest in 
early-life (Wolf et al., 1998) and could act through for example, yolkdeposited components in the egg (Criscuolo et al., 2020; Noguera et al., 2020; Stier, Hsu, et al., 2020) or post-laying through maternal care behaviour (e.g., incubation and feeding rate, Stier et al., 2020; Viblanc et al., 2020). Our results suggest that such effects may have a genetic basis that will respond to selection: For heritable traits like $T L$, maternal inheritance of offspring TL may be expected to increase the expected rate of adaptive evolution of TL above what would be expected from the heritability alone (Hadfield, 2012; Lande \& Kirkpatrick, 1990; Räsänen \& Kruuk, 2007; Wolf et al., 1998).

There was evidence for additive genetic variance in the tarsus length of sparrow nestlings, but the heritability estimate $\left(h^{2}=0.080\right.$, Table 2) was considerably smaller than those of adult house sparrows in a larger sample of populations in the same area (Araya-Ajoy et al., 2019; Jensen et al., 2008) and other bird species (Merilä \& Sheldon, 2001). However, there was a large brood effect on nestling tarsus length suggesting common environmental effects within broods (e.g., Potti \& Merino, 1994). For instance, variation in clutch size, seasonal differences in food availability, weather conditions (Ringsby et al., 2002), and provisioning rates by parents (Ringsby et al., 2009) may induce intraclutch competition and variation in the degree to which nestlings are able to achieve their adult tarsus lengths at fledging (Metcalfe \& Monaghan, 2001; Naef-Daenzer \& Keller, 1999). Furthermore, measurement error is probably higher for the incompletely ossified nestling tarsi, which are covered by a soft fleshy skin tissue that contributes to the measured length.

Individuals with shorter tarsi (a proxy for structural size, ArayaAjoy et al., 2019) were found to have longer telomeres, although the effect of tarsus length on TL was small and there was considerable variation in TL for a given size (Figure 1). This confirms previous observations of a prevailing negative phenotypic correlation between body size and TL within house sparrows (Pepke et al., 2021; Ringsby et al., 2015) and other species (Monaghan \& Ozanne, 2018). We did not find any evidence of a significant negative genetic correlation between TL and tarsus length (Table 2). Instead, the negative phenotypic association between TL and tarsus length may have no genetic basis but is shaped by common environmental effects that affect both traits in opposite directions (e.g., Kruuk et al., 2008) including processes related to the incomplete replication of chromosome ends during cell division and increased oxidative stress during growth (e.g., Monaghan \& Ozanne, 2018). The lack of a genetic correlation between TL, tarsus length or body condition could also be attributed to selection acting simultaneously on some correlated, unmeasured trait (Merilä et al., 2001). Both with and without controlling for the effect of tarsus length on TL, our GWAS on TL identified several genes involved in skeletal development, cellular growth and differentiation that may regulate body growth or size (Table 4, Tables S2.5 and S2.7 in Appendix S2), which could, however, suggest some genetic basis of the negative correlation between TL and size. For instance, several growth factors were downregulated in telomerase deficient mouse bone marrow stromal stem cells (Saeed \& lqtedar, 2015) suggesting that short telomeres or telomere loss could also be a constraint on proliferation potential. Thus, because several of the genes that may regulate TL during early development appear to also be involved in cell proliferation or morphogenesis, such genes may have co-evolved.

None of the genes highlighted in our analysis have previously been linked to TL in GWA studies (reviewed in the introduction). Table 4 does not provide an exhaustive list of potential biological processes or molecular functions associated with variation in $\mathrm{TL}$, and with little a priori information on the identified SNPs, we are cautious in interpreting these apparent associations as causal (Pavlidis et al., 2012). Furthermore, the low heritability and polygenic nature of TL make it challenging to identify putative causal genes, which consequently only explain a small part of the total phenotypic variance in TL, and our limited sample size $(n=383)$ is likely to upwardly bias effect sizes and SNP heritabilities due to the Beavis effect (Slate, 2013). Our GWAS on TL was limited to a subset of recruiting individuals, which may affect power to detect associations between SNPs and $T L$ if the genotype or phenotype affects recruitment probability. Pepke et al. (2021) found no association between TL and first-year survival in house sparrows, but that recruits had longer tarsi.

Several of the identified candidate genes (Table 4, Tables S2.5 and S2.7 in Appendix S2) are involved in cell proliferation and apoptosis during which $\mathrm{TL}$ and telomerase activity invariably play an important role (Greider, 1998; Masutomi et al., 2003). Telomerase activity has not been investigated in house sparrows. However, for example the RHOF gene product functions cooperatively with CDC42 and Rac to organize the actin cytoskeleton (Ellis \& Mellor, 2000), and the latter complex participates in the control of telomerase activity in human cancer cells (Yeh et al., 2005). CDC42 is activated by FGD4 (Chen et al., 2004), which was found within a major locus affecting TL in humans (Vasa-Nicotera et al., 2005). SNPa108592 was found near several genes involved in cell proliferation, differentiation, immune response, and ubiquitination (Table 4). Ubiquitination regulates several shelterin components and telomerase activity (Peuscher \& Jacobs, 2012; Yalçin et al., 2017). The closest gene, ORAI1 (43 kb), the keeper of the gates of calcium ions (Homer, 1924), is crucial for lymphocyte activation and immune response (Feske et al., 2006). Although not linked to ORAl1 mutations, calcium ion levels can modulate telomerase activity (reviewed in Farfariello et al., 2015).

We identified a particularly interesting gene associated with TL, AQP1. The AQP1 channel not only conducts water across cell membranes, but also hydrogen peroxide, a major reactive oxygen species (ROS, Tamma et al., 2018), and nitric oxide (Herrera et al., 2006), which is an important regulator of oxidative stress (Pierini \& Bryan, 2015) and a weak oxidant itself (Radi, 2018). Furthermore, increased availability of nitric oxide may activate telomerase and thereby prevent replicative senescence (in endothelial cells, Vasa et al., 2000). Enhanced oxidative stress associated with endothelial cell senescence may also be mediated by AQP1-regulated nitric oxide flow (Chen et al., 2020; Tamma et al., 2018). In AQP1 knocked-out erythrocytes (where TL was measured) cell lifespan was shortened (Mathai et al., 1996) and angiogenesis is inhibited in AQP1 knockedout chicken embryos (Camerino et al., 2006) and mice (Saadoun et al., 2005). Telomeres are particularly sensitive to ROS and shorten 
due to oxidative stress during growth (Reichert \& Stier, 2017; von Zglinicki, 2002). For example, Kim et al. (2011) found a negative genetic correlation between growth and resistance to oxidative stress in yellow-legged gull (Larus michahellis) chicks, which could be mediated by TL (see also Smith et al., 2016). Another candidate gene, OXR1, $76 \mathrm{~kb}$ from SNPa450086, has a well-described antioxidant function (Oliver et al., 2011; Volkert et al., 2000) and is upregulated in senescent human cells (Zhang et al., 2018). Knockdown of OXR1 increases ROS production and ultimately induces apoptosis (Oliver et al., 2011; Zhang et al., 2018), which could be due to telomere crisis.

Over-expression of AQP1 has been associated with several types of cancer (Verkman et al., 2008), suppression of apoptosis (Yamazato et al., 2018) and may play an important role in tumour biology (Saadoun et al., 2005; Tomita et al., 2017). Other candidate genes including GHRHR, SHCBP1 (Tao et al., 2013), GH (Boguszewski \& Boguszewski, 2019), and OXR1 (Yang et al., 2015) are also involved in tumorigenesis. Cancer prevalence is not well-studied in wildlife (Pesavento et al., 2018), but tumours have been documented in house sparrows (Møller et al., 2017). Genes affecting both TL and cancer risk (Jones et al., 2012; Tacutu et al., 2011) could underlie the antagonistic pleiotropy of trade-offs between long telomeres in early-life (with potential benefits to growth, reproduction, and other oxidative stress inducing processes) and later-life cancer mortality (Tian et al., 2018). Cancer is often viewed as a senescence-related pathology (Lemaître et al., 2020). However, the absence of cancer in early-life should not lead us to conclude that a somatic and potentially fitness-related cost is not paid to maintain that status (Thomas et al., 2018).

We have shown that TL is a heritable, polygenic trait with considerable environmental variation and a maternal inheritance component in a wild passerine. It is, however, important that future studies attempt to confirm the putative candidate genes identified here as associated with TL in other wild populations. Even though the additive genetic component was small, selection on variation in TL may produce evolutionary change in TL over time in wild populations. The large component of variation in early-life TL caused by annual environmental stochasticity suggests that this will generate heterogeneity in TL among cohorts. Although we did not find a negative genetic correlation underlying the negative phenotypic correlation between TL and body size, we may hypothesize that selection for larger nestling size, which may enhance survival until recruitment (Ringsby et al., 1998), will be associated with selection for shorter early-life TL due to nongenetic mechanisms, which can ultimately influence lifespan or reproductive success.

\section{ACKNOWLEDGEMENTS}

We thank all field workers who collected data for this study and the island inhabitants that made it possible, laboratory technician Randi Røsbak (NTNU, Trondheim) for extracting DNA and microsatellite genotyping, Darryl McLennan (University of Glasgow) for help with telomere data analyses, Yimen Araya-Ajoy (NTNU, Trondheim) for helpful comments on an earlier version of this manuscript, and
"Forsknings- og undervisningsfondet i Trondheim" for financial support (to MLP). This work was funded by the Research Council of Norway (274930) and through its Centres of Excellence scheme (223257). The study was carried out in accordance with permits from the Norwegian Animal Research Authority (FOTS id 11904) and the Ringing Centre at Stavanger Museum, Norway.

\section{CONFLICT OF INTEREST}

The authors declare no conflicts of interest.

\section{AUTHOR CONTRIBUTIONS}

Michael Le Pepke measured telomeres, analysed the data, and wrote the manuscript with comments from all authors. Winnie Boner and Pat Monaghan advised telomere measurements. Thomas Kvalnes, Henrik Jensen, Thor Harald Ringsby, and Sarah Lundregan advised statistical analyses. Bernt-Erik Sæther, Thor Harald Ringsby, and Henrik Jensen established the study system. Thor Harald Ringsby, Henrik Jensen, and Thomas Kvalnes contributed to the fieldwork.

\section{DATA AVAILABILITY STATEMENT}

Data has been made available on Dryad (https://doi.org/10.5061/ dryad.80gb5mks0). SNP genotype data has been made available on Dryad (https://doi.org/10.5061/dryad.hp758sn).

\section{ORCID}

Michael Le Pepke (D) https://orcid.org/0000-0002-6280-1829

Thomas Kvalnes (D) https://orcid.org/0000-0002-3088-7891

Sarah Lundregan (D) https://orcid.org/0000-0002-4971-6208

Winnie Boner (D) https://orcid.org/0000-0003-1702-4298

Pat Monaghan (D) https://orcid.org/0000-0003-2430-0326

Bernt-Erik Sæther (D) https://orcid.org/0000-0002-0049-9767

Henrik Jensen (D) https://orcid.org/0000-0001-7804-1564

Thor Harald Ringsby (D) https://orcid.org/0000-0001-9089-7592

\section{REFERENCES}

Abdullah, J. M., Jing, X., Spassov, D. S., Nachtman, R. G., \& Jurecic, R. (2001). Cloning and characterization of hepp, a novel gene expressed preferentially in hematopoietic progenitors and mature blood cells. Blood Cells, Molecules, and Diseases, 27(3), 667-676. https://doi.org/10.1006/bcmd.2001.0434

Akaike, H. (1973). Information theory and an extension of the maximum likelihood principle. Paper presented at the Second International Symposium on Information Theory, Akademiai Kiado, Budapest.

Akiduki, S., \& Ikemoto, M. J. (2008). Modulation of the neural glutamate transporter EAAC1 by the addicsin-interacting protein ARL6IP1. Journal of Biological Chemistry, 283(46), 31323-31332. https://doi. org/10.1074/jbc.M801570200

Andrew, T., Aviv, A., Falchi, M., Surdulescu, G. L., Gardner, J. P., Lu, X., Kimura, M., Kato, B. S., Valdes, A. M., \& Spector, T. D. (2006). Mapping genetic loci that determine leukocyte telomere length in a large sample of unselected female sibling Pairs. The American Journal of Human Genetics, 78(3), 480-486. https://doi. org/10.1086/500052

Araya-Ajoy, Y. G., Ranke, P. S., Kvalnes, T., Rønning, B., Holand, H., Myhre, A. M., Pärn, H., Jensen, H., Ringsby, T. H., Sæther, B.-E., \& Wright, J. (2019). Characterizing morphological (co)variation using structural 
equation models: Body size, allometric relationships and evolvability in a house sparrow metapopulation. Evolution, 73(3), 452-466. https://doi.org/10.1111/evo.13668

Asano, E., Hasegawa, H., Hyodo, T., Ito, S., Maeda, M., Chen, D., Takahashi, M., Hamaguchi, M., \& Senga, T. (2014). SHCBP1 is required for midbody organization and cytokinesis completion. Cell Cycle, 13(17), 2744-2751. https://doi.org/10.4161/15384 101.2015.945840

Asghar, M., Bensch, S., Tarka, M., Hansson, B., \& Hasselquist, D. (2015). Maternal and genetic factors determine early life telomere length. Proceedings of the Royal Society B: Biological Sciences, 282(1799), 20142263. https://doi.org/10.1098/rspb.2014.2263

Aulinas, A., Ramírez, M. J., Barahona, M. J., Mato, E., Bell, O., Surrallés, J., $\&$ Webb, S. M. (2013). Telomeres and endocrine dysfunction of the adrenal and GH/IGF-1 axes. Clinical Endocrinology, 79(6), 751-759. https://doi.org/10.1111/cen.12310

Aviv, A. (2012). Genetics of leukocyte telomere length and its role in atherosclerosis. Mutation Research/Fundamental and Molecular Mechanisms of Mutagenesis, 730(1), 68-74. https://doi. org/10.1016/j.mrfmmm.2011.05.001

Banks, W. A., Morley, J. E., Farr, S. A., Price, T. O., Ercal, N., Vidaurre, I., \& Schally, A. V. (2010). Effects of a growth hormone-releasing hormone antagonist on telomerase activity, oxidative stress, longevity, and aging in mice. Proceedings of the National Academy of Sciences of the United States of America, 107(51), 22272-22277. https://doi. org/10.1073/pnas.1016369107

Bates, D., Mächler, M., Bolker, B., \& Walker, S. (2015). Fitting linear mixed-effects models using Ime4. Journal of Statistical Software, 67(1), 1-48. https://doi.org/10.18637/jss.v067.i01

Bateson, M. (2016). Cumulative stress in research animals: Telomere attrition as a biomarker in a welfare context? BioEssays, 38(2), 201212. https://doi.org/10.1002/bies.201500127

Batrakou, D. G., de las Heras, J. I., Czapiewski, R., Mouras, R., \& Schirmer, E. C. (2015). TMEM120A and B: Nuclear envelope transmembrane proteins important for adipocyte differentiation. PLoS One, 10(5), e0127712. https://doi.org/10.1371/journal.pone.0127712

Bauch, C., Boonekamp, J. J., Korsten, P., Mulder, E., \& Verhulst, S. (2019). Epigenetic inheritance of telomere length in wild birds. PLoS Genetics, 15(2), e1007827. https://doi.org/10.1371/journ al.pgen.1007827

Bauch, C., Boonekamp, J. J., Korsten, P., Mulder, E., \& Verhulst, S. (2021). High heritability of telomere length and low heritability of telomere shortening in wild birds. Molecular Ecology, 00, 1-16. https://doi. org/10.1111/mec.16183

Becker, P. J. J., Reichert, S., Zahn, S., Hegelbach, J., Massemin, S., Keller, L. F., Postma, E., \& Criscuolo, F. (2015). Mother-offspring and nest-mate resemblance but no heritability in early-life telomere length in white-throated dippers. Proceedings of the Royal Society $B$ : Biological Sciences, 282(1807), 20142924. https://doi.org/10.1098/ rspb.2014.2924

Bergstein, I., Eisenberg, L. M., Bhalerao, J., Jenkins, N. A., Copeland, N. G., Osborne, M. P., Bowcock, A. M., \& Brown, A. M. C. (1997). Isolation of two novel WNT genes, WNT14 and WNT15, one of which (WNT15) is closely linked to WNT3 on human chromosome 17q21. Genomics, 46(3), 450-458. https://doi.org/10.1006/ geno.1997.5041

Bichet, C., Bouwhuis, S., Bauch, C., Verhulst, S., Becker, P. H., \& Vedder, O. (2020). Telomere length is repeatable, shortens with age and reproductive success, and predicts remaining lifespan in a longlived seabird. Molecular Ecology, 29(2), 429-441. https://doi. org/10.1111/mec.15331

Billing, A. M., Lee, A. M., Skjelseth, S., Borg, Å. A., Hale, M. C., Slate, J., Pärn, H., Ringsby, T. H., Saether, B.-E., \& Jensen, H. (2012). Evidence of inbreeding depression but not inbreeding avoidance in a natural house sparrow population. Molecular Ecology, 21(6), 1487-1499. https://doi.org/10.1111/j.1365-294X.2012.05490.x
Binns, D., Dimmer, E., Huntley, R., Barrell, D., O'Donovan, C., \& Apweiler, R. (2009). QuickGO: A web-based tool for gene ontology searching. Bioinformatics, 25(22), 3045-3046. https://doi.org/10.1093/bioin formatics/btp536

Bize, P., Criscuolo, F., Metcalfe, N. B., Nasir, L., \& Monaghan, P. (2009). Telomere dynamics rather than age predict life expectancy in the wild. Proceedings of the Royal Society B-Biological Sciences, 276(1662), 1679-1683. https://doi.org/10.1098/rspb.2008.1817

Blackburn, E. H. (1991). Structure and function of telomeres. Nature, 350(6319), 569-573. https://doi.org/10.1038/350569a0

Blackburn, E. H., Epel, E. S., \& Lin, J. (2015). Human telomere biology: A contributory and interactive factor in aging, disease risks, and protection. Science, 350(6265), 1193-1198. https://doi.org/10.1126/ science.aab3389

Boguszewski, C. L., \& Boguszewski, M. (2019). Growth hormone's links to cancer. Endocrine Reviews, 40(2), 558-574. https://doi.org/10.1210/ er.2018-00166

Bonferroni, C. E. (1935). II calcolo delle assicurazioni su gruppi di teste [The calculation of significance with multiple tests]. Studi in Onore del Professore Salvatore Ortu Carboni [Studies in Honor of Professor Salvatore Ortu Carbon], (pp. 13-60). Rome, Italy: Bardi.

Boonekamp, J. J., Mulder, G. A., Salomons, H. M., Dijkstra, C., \& Verhulst, S. (2014). Nestling telomere shortening, but not telomere length, reflects developmental stress and predicts survival in wild birds. Proceedings of the Royal Society B: Biological Sciences, 281(1785), 20133287. https://doi.org/10.1098/rspb.2013.3287

Boonekamp, J., Rodríguez-Muñoz, R., Hopwood, P., Zuidersma, E., Mulder, E., Wilson, A., Verhulst, S., \& Tregenza, T. (2021). Telomere length is highly heritable and independent of growth rate manipulated by temperature in field crickets. Molecular Ecology, 00, 0-13. https://doi.org/10.1111/mec.15888

Boonekamp, J. J., Simons, M. J., Hemerik, L., \& Verhulst, S. (2013). Telomere length behaves as biomarker of somatic redundancy rather than biological age. Aging Cell, 12(2), 330-332. https://doi. org/10.1111/acel.12050

Bourhis, E., Tam, C., Franke, Y., Bazan, J. F., Ernst, J., Hwang, J., Costa, M., Cochran, A. G., \& Hannoush, R. N. (2010). Reconstitution of a Frizzled8.Wnt3a.LRP6 signaling complex reveals multiple Wnt and Dkk1 binding sites on LRP6. Journal of Biological Chemistry, 285(12), 9172-9179. https://doi.org/10.1074/jbc.M109.092130

Broer, L., Codd, V., Nyholt, D. R., Deelen, J., Mangino, M., Willemsen, G., \& Boomsma, D. I. (2013). Meta-analysis of telomere length in 19,713 subjects reveals high heritability, stronger maternal inheritance and a paternal age effect. European Journal of Human Genetics, 21(10), 1163-1168. https://doi.org/10.1038/ejhg.2012.303

Buckley, M. W., Arandjelovic, S., Trampont, P. C., Kim, T. S., Braciale, T. J., $\&$ Ravichandran, K. S. (2014). Unexpected phenotype of mice lacking Shcbp1, a protein induced during T cell proliferation. PLoS One, 9(8), e105576. https://doi.org/10.1371/journal.pone.0105576

Burnham, K. P., \& Anderson, D. R. (2002). Model selection and multimodel inference. A practical information-theoretic approach, 2nd ed. Springer-Verlag.

Byerly, M. S., Simon, J., Cogburn, L. A., Le Bihan-Duval, E., Duclos, M. J., Aggrey, S. E., \& Porter, T. E. (2010). Transcriptional profiling of hypothalamus during development of adiposity in genetically selected fat and lean chickens. Physiological Genomics, 42(2), 157-167. https://doi.org/10.1152/physiolgenomics.00029.2010

Camerino, G. M., Nicchia, G. P., Dinardo, M. M., Ribatti, D., Svelto, M., \& Frigeri, A. (2006). In vivo silencing of aquaporin-1 by RNA interference inhibits angiogenesis in the chick embryo chorioallantoic membrane assay. Cellular and Molecular Biology, 52(7), 51-56.

Cawthon, R. M. (2002). Telomere measurement by quantitative PCR. Nucleic Acids Research, 30(10), 47e-47. https://doi.org/10.1093/ nar/30.10.e47

Chatelain, M., Drobniak, S. M., \& Szulkin, M. (2020). The association between stressors and telomeres in non-human vertebrates: 
A meta-analysis. Ecology Letters, 23(2), 381-398. https://doi. org/10.1111/ele.13426

Chen, M., Li, Y., Xiao, L., Dai, G., Lu, P., Wang, Y., \& Rui, Y. (2020). AQP1 modulates tendon stem/progenitor cells senescence during tendon aging. Cell Death \& Disease, 11(3), 193. https://doi.org/10.1038/ s41419-020-2386-3

Chen, X. M., Splinter, P. L., Tietz, P. S., Huang, B. Q., Billadeau, D. D., \& LaRusso, N. F. (2004). Phosphatidylinositol 3-kinase and frabin mediate Cryptosporidium parvum cellular invasion via activation of Cdc42. Journal of Biological Chemistry, 279(30), 31671-31678. https://doi.org/10.1074/jbc.M401592200

Chu, W. K., Law, K. S., Chan, S. O., Yam, J. C. S., Chen, L. J., Zhang, H. Cheung, H. S., Block, N. L., Schally, A. V., \& Pang, C. P. (2016). Antagonists of growth hormone-releasing hormone receptor induce apoptosis specifically in retinoblastoma cells. Proceedings of the National Academy of Sciences of the United States of America, 113(50), 14396-14401. https://doi.org/10.1073/pnas.1617427113

Codd, V., Mangino, M., van der Harst, P., Braund, P. S., Kaiser, M., Beveridge, A. J., Rafelt, S., Moore, J., Nelson, C., Soranzo, N., Zhai, G., Valdes, A. M., Blackburn, H., Leach, I. M., de Boer, R. A., Kimura, M., Aviv, A., Goodall, A. H., Ouwehand, W., ... Samani, N. J. (2010). Common variants near TERC are associated with mean telomere length. Nature Genetics, 42(3), 197-199. https://doi.org/10.1038/ ng.532

Codd, V., Nelson, C. P., Albrecht, E., Mangino, M., Deelen, J., Buxton, J. L., Hottenga, J. J., Fischer, K., Esko, T., Surakka, I., Broer, L., Nyholt, D. R., Leach, I. M., Salo, P., Hägg, S., Matthews, M. K., Palmen, J., Norata, G. D., O'Reilly, P. F., ... Samani, N. J. (2013). Identification of seven loci affecting mean telomere length and their association with disease. Nature Genetics, 45(4), 422-427. https://doi. org/10.1038/ng.2528

Coster, A. (2012). pedigree: Pedigree functions. R package version 1.4 . https://CRAN.R-project.org/package=pedigree

Coutts, F., Palmos, A. B., Duarte, R. R. R., de Jong, S., Lewis, C. M., Dima, D., \& Powell, T. R. (2019). The polygenic nature of telomere length and the anti-ageing properties of lithium. Neuropsychopharmacology, 44(4), 757-765. https://doi.org/10.1038/s41386-018-0289-0

Criscuolo, F., Bize, P., Nasir, L., Metcalfe, N. B., Foote, C. G., Griffiths, K., Gault, E. A., \& Monaghan, P. (2009). Real-time quantitative PCR assay for measurement of avian telomeres. Journal of Avian Biology, 40(3), 342-347. https://doi.org/10.1111/j.1600-048X.2008.04623.x

Criscuolo, F., Torres, R., Zahn, S., \& Williams, T. D. (2020). Telomere dynamics from hatching to sexual maturity and maternal effects in the 'multivariate egg'. The Journal of Experimental Biology, 223(23), jeb232496. https://doi.org/10.1242/jeb.232496

Dantzer, B., \& Fletcher, Q. E. (2015). Telomeres shorten more slowly in slow-aging wild animals than in fast-aging ones. Experimental Gerontology, 71, 38-47. https://doi.org/10.1016/j. exger.2015.08.012

de Villemereuil, P., Morrissey, M. B., Nakagawa, S., \& Schielzeth, H. (2018). Fixed-effect variance and the estimation of repeatabilities and heritabilities: Issues and solutions. Journal of Evolutionary Biology, 31(4), 621-632. https://doi.org/10.1111/jeb.13232

Deelen, J., Uh, H.-W., Monajemi, R., van Heemst, D., Thijssen, P. E., Böhringer, S., van den Akker, E. B., de Craen, A. J. M., Rivadeneira, F., Uitterlinden, A. G., Westendorp, R. G. J., Goeman, J. J., Slagboom, P. E., Houwing-Duistermaat, J. J., \& Beekman, M. (2013). Gene set analysis of GWAS data for human longevity highlights the relevance of the insulin/IGF-1 signaling and telomere maintenance pathways. Age (Dordrecht, Netherlands), 35(1), 235-249. https://doi. org/10.1007/s11357-011-9340-3

Delgado, D. A., Zhang, C., Chen, L. S., Gao, J., Roy, S., Shinkle, J., Sabarinathan, M., Argos, M., Tong, L., Ahmed, A., Islam, T., RakibuzZaman, M., Sarwar, G., Shahriar, H., Rahman, M., Yunus, M., Jasmine, F., Kibriya, M. G., Ahsan, H., \& Pierce, B. L. (2018). Genome-wide association study of telomere length among South Asians identifies a second RTEL1 association signal. Journal of Medical Genetics, 55(1), 64-71. https://doi.org/10.1136/jmedgenet-2017-104922

Dugdale, H. L., \& Richardson, D. S. (2018). Heritability of telomere variation: It is all about the environment! Philosophical Transactions of the Royal Society of London. Series B, Biological Sciences, 373(1741), 20160450. https://doi.org/10.1098/rstb.2016.0450

Eastwood, J. R., Hall, M. L., Teunissen, N., Kingma, S. A., Hidalgo Aranzamendi, N., Fan, M., Roast, M., Verhulst, S., \& Peters, A. (2019). Early-life telomere length predicts lifespan and lifetime reproductive success in a wild bird. Molecular Ecology, 28(5), 11271137. https://doi.org/10.1111/mec.15002

Eisenberg, D. T. A. (2011). An evolutionary review of human telomere biology: The thrifty telomere hypothesis and notes on potential adaptive paternal effects. American Journal of Human Biology, 23(2), 149-167. https://doi.org/10.1002/ajhb.21127

Eisenberg, D. T. A. (2014). Inconsistent inheritance of telomere length $(T L)$ : Is offspring TL more strongly correlated with maternal or paternal TL? European Journal of Human Genetics, 22(1), 8-9. https:// doi.org/10.1038/ejhg.2013.202

Eisenberg, D. T. A., \& Kuzawa, C. W. (2018). The paternal age at conception effect on offspring telomere length: Mechanistic, comparative and adaptive perspectives. Philosophical Transactions of the Royal Society B: Biological Sciences, 373(1741), 20160442. https://doi. org/10.1098/rstb.2016.0442

Elgvin, T. O., Trier, C. N., Tørresen, O. K., Hagen, I. J., Lien, S., Nederbragt, A. J., Ravinet, M., Jensen, H., \& Sætre, G.-P. (2017). The genomic mosaicism of hybrid speciation. Science Advances, 3(6), e1602996. https://doi.org/10.1126/sciadv.1602996

Ellegren, H., \& Sheldon, B. C. (2008). Genetic basis of fitness differences in natural populations. Nature, 452(7184), 169-175. https://doi. org/10.1038/nature06737

Ellis, S., \& Mellor, H. (2000). The novel Rho-family GTPase Rif regulates coordinated actin-based membrane rearrangements. Current Biology, 10(21), 1387-1390. https://doi.org/10.1016/S0960 -9822(00)00777-6

Erten, E. Y., \& Kokko, H. (2020). From zygote to a multicellular soma: Body size affects optimal growth strategies under cancer risk. Evolutionary Applications, 13(7), 1593-1604. https://doi. org/10.1111/eva.12969

Falconer, D. S., \& Mackay, T. F. C. (1996). Introduction to quantitative genetics. Benjamin-Cummings Pub Co.

Farfariello, V., lamshanova, O., Germain, E., Fliniaux, I., \& Prevarskaya, N. (2015). Calcium homeostasis in cancer: A focus on senescence. Biochimica et Biophysica Acta (BBA) - Molecular. Cell Research, 1853(9), 1974-1979. https://doi.org/10.1016/j.bbamcr.2015.03.005

Feske, S., Gwack, Y., Prakriya, M., Srikanth, S., Puppel, S.-H., Tanasa, B., Hogan, P. G., Lewis, R. S., Daly, M., \& Rao, A. (2006). A mutation in Orai1 causes immune deficiency by abrogating CRAC channel function. Nature, 441(7090), 179-185. https://doi.org/10.1038/ nature 04702

Foley, N. M., Petit, E. J., Brazier, T., Finarelli, J. A., Hughes, G. M., Touzalin, F., \& Teeling, E. C. (2020). Drivers of longitudinal telomere dynamics in a long-lived bat species, Myotis myotis. Molecular Ecology, 29(16), 2963-2977. https://doi.org/10.1111/mec.15395

Froy, H., Underwood, S. L., Dorrens, J., Seeker, L. A., Watt, K., Wilbourn, R. V., Pilkington, J. G., Harrington, L., Pemberton, J. M., \& Nussey, D. H. (2021). Heritable variation in telomere length predicts mortality in Soay sheep. Proceedings of the National Academy of Sciences, 118(15), e2020563118. https://doi.org/10.1073/pnas.2020563118

Fyhrquist, F., Saijonmaa, O., \& Strandberg, T. (2013). The roles of senescence and telomere shortening in cardiovascular disease. Nature Reviews Cardiology, 10(5), 274-283. https://doi.org/10.1038/nrcar dio. 2013.30

Garcia, J. A., Ou, S. H., Wu, F., Lusis, A. J., Sparkes, R. S., \& Gaynor, R. B. (1992). Cloning and chromosomal mapping of a human immunodeficiency virus 1 "TATA" element modulatory factor. Proceedings 
of the National Academy of Sciences, 89(20), 9372. https://doi org/10.1073/pnas.89.20.9372

GenABEL project developers. (2013). GenABEL: Genome-wide SNP association analysis. R package version 1.8-0. https://CRAN.R-proje ct.org $/$ package $=$ GenABEL

Gómez-García, L., Sánchez, F. M., Vallejo-Cremades, M. T., de Segura, I. A., \& del Campo Ede, M. (2005). Direct activation of telomerase by $\mathrm{GH}$ via phosphatidylinositol 3'-kinase. Journal of Endocrinology, 185(3), 421-428. https://doi.org/10.1677/joe.1.05766

Gong, L., \& Yeh, E. T. (1999). Identification of the activating and conjugating enzymes of the NEDD8 conjugation pathway. Journal of Biological Chemistry, 274(17), 12036-12042. https://doi. org/10.1074/jbc.274.17.12036

Greider, C. W. (1998). Telomeres and senescence: The history, the experiment, the future. Current Biology, 8(5), R178-R181. https://doi. org/10.1016/S0960-9822(98)70105-8

Griffiths, R., Double, M. C., Orr, K., \& Dawson, R. J. (1998). A DNA test to sex most birds. Molecular Ecology, 7(8), 1071-1075. https://doi. org/10.1046/j.1365-294x.1998.00389.x

Hadfield, J. (2010). MCMC methods for multi-response generalized linear mixed models: The MCMCgImm R package. Journal of Statistical Software, 1(2), 1-22. https://doi.org/10.18637/jss.v033.i02

Hadfield, J. (2012). Chapter 15: The quantitative genetic theory of parental effects. In N. J. Royle, P. T. Smiseth \& M. Kölliker (Eds.), The evolution of parental care (pp. 267-284). OUP Oxford.

Hadfield, J. (2019). MCMCgImm course notes. Retrieved from http:// cran.r-project.org/web/packages/MCMCglmm/vignettes/Cours eNotes.pdf

Hadfield, J. D., Richardson, D. S., \& Burke, T. (2006). Towards unbiased parentage assignment: Combining genetic, behavioural and spatial data in a Bayesian framework. Molecular Ecology, 15(12), 37153730. https://doi.org/10.1111/j.1365-294X.2006.03050.x

Hagen, I. J., Billing, A. M., Ronning, B., Pedersen, S. A., Parn, H., Slate, J., \& Jensen, H. (2013). The easy road to genome-wide medium density SNP screening in a non-model species: Development and application of a 10K SNP-chip for the house sparrow (Passer domesticus). Molecular Ecology Resources, 13(3), 429-439. https://doi. org/10.1111/1755-0998.12088

Hagen, I. J., Lien, S., Billing, A. M., Elgvin, T. O., Trier, C., Niskanen, A. K., \& Jensen, H. (2020). A genome-wide linkage map for the house sparrow (Passer domesticus) provides insights into the evolutionary history of the avian genome. Molecular Ecology Resources, 20(2), 544-559. https://doi.org/10.1111/1755-0998.13134

Hansen, M. E. B., Hunt, S. C., Stone, R. C., Horvath, K., Herbig, U., Ranciaro, A., Hirbo, J., Beggs, W., Reiner, A. P., Wilson, J. G., Kimura, M., De Vivo, I., Chen, M. M., Kark, J. D., Levy, D., Nyambo, T., Tishkoff, S. A., \& Aviv, A. (2016). Shorter telomere length in Europeans than in Africans due to polygenetic adaptation. Human Molecular Genetics, 25(11), 2324-2330. https://doi.org/10.1093/hmg/ddw070

Hay, J. C., Chao, D. S., Kuo, C. S., \& Scheller, R. H. (1997). Protein interactions regulating vesicle transport between the endoplasmic reticulum and Golgi apparatus in mammalian cells. Cell, 89(1), 149-158. https://doi.org/10.1016/S0092-8674(00)80191-9

Heidelberger, P., \& Welch, P. D. (1983). Simulation run length control in the presence of an initial transient. Operations Research, 31(6), 1109-1144. https://doi.org/10.1287/opre.31.6.1109

Heidinger, B. J., Blount, J. D., Boner, W., Griffiths, K., Metcalfe, N. B., \& Monaghan, P. (2012). Telomere length in early life predicts lifespan. Proceedings of the National Academy of Sciences of the United States of America, 109(5), 1743-1748. https://doi.org/10.1073/ pnas.1113306109

Heidinger, B. J., Herborn, K. A., Granroth-Wilding, H. M. V., Boner, W., Burthe, S., Newell, M., Wanless, S., Daunt, F., \& Monaghan, P. (2016). Parental age influences offspring telomere loss. Functional Ecology, 30(9), 1531-1538. https://doi.org/10.1111/1365-2435.12630
Heidinger, B. J., Kucera, A. C., Kittilson, J. D., \& Westneat, D. F. (2021). Longer telomeres during early life predict higher lifetime reproductive success in females but not males. Proceedings of the Royal Society B: Biological Sciences, 288(1951), 20210560. https://doi. org/10.1098/rspb.2021.0560

Hellemans, J., Mortier, G., De Paepe, A., Speleman, F., \& Vandesompele, J. (2007). qBase relative quantification framework and software for management and automated analysis of real-time quantitative PCR data. Genome Biology, 8(2), R19. https://doi.org/10.1186/ gb-2007-8-2-r19

Herbig, U., Ferreira, M., Condel, L., Carey, D., \& Sedivy, J. M. (2006). Cellular senescence in aging primates. Science, 311(5765), 1257. https://doi.org/10.1126/science.1122446

Herrera, M., Hong Nancy, J., \& Garvin Jeffrey, L. (2006). Aquaporin-1 transports NO across cell membranes. Hypertension, 48(1), 157164. https://doi.org/10.1161/01.HYP.0000223652.29338.77

Hill, W. G. (2010). Understanding and using quantitative genetic variation. Philosophical Transactions of the Royal Society B: Biological Sciences, 365(1537), 73-85. https://doi.org/10.1098/rstb.2009.0203

Homer, (1924). The lliad (book 5, lines 749-750; book 8, lines 393-394 and 433). Harvard University Press. William Heinemann Ltd.

Horn, T., Robertson, B. C., Will, M., Eason, D. K., Elliott, G. P., \& Gemmell, N. J. (2011). Inheritance of telomere length in a bird. PLoS One, 6(2), e17199. https://doi.org/10.1371/journal.pone.0017199

Houben, J. M. J., Moonen, H. J. J., van Schooten, F. J., \& Hageman, G. J. (2008). Telomere length assessment: Biomarker of chronic oxidative stress? Free Radical Biology and Medicine, 44(3), 235-246. https://doi.org/10.1016/j.freeradbiomed.2007.10.001

Huntley, R. P., Sawford, T., Mutowo-Meullenet, P., Shypitsyna, A., Bonilla, C., Martin, M. J., \& O'Donovan, C. (2015). The GOA database: Gene Ontology annotation updates for 2015. Nucleic Acids Research, 43(D1), D1057-D1063. https://doi.org/10.1093/nar/gku1113

Hurvich, C. M., \& Tsai, C.-L. (1989). Regression and time series model selection in small samples. Biometrika, 76(2), 297-307. https://doi. org/10.1093/biomet/76.2.297

Ikenouchi, J., \& Umeda, M. (2010). FRMD4A regulates epithelial polarity by connecting Arf6 activation with the PAR complex. Proceedings of the National Academy of Sciences, 107(2), 748. https://doi. org/10.1073/pnas.0908423107

Ilska-Warner, J. J., Psifidi, A., Seeker, L. A., Wilbourn, R. V., Underwood, S. L., Fairlie, J., Whitelaw, B., Nussey, D. H., Coffey, M. P., \& Banos, G. (2019). The genetic architecture of bovine telomere length in early life and association with animal fitness. Frontiers in Genetics, 10(1048), 1-13. https://doi.org/10.3389/fgene.2019.01048

Jennings, B. J., Ozanne, S. E., \& Hales, C. N. (2000). Nutrition, oxidative damage, telomere shortening, and cellular senescence: Individual or connected agents of aging? Molecular Genetics and Metabolism, 71(1), 32-42. https://doi.org/10.1006/mgme.2000.3077

Jensen, H., Sæther, B. E., Ringsby, T. H., Tufto, J., Griffith, S. C., \& Ellegren, H. (2003). Sexual variation in heritability and genetic correlations of morphological traits in house sparrow (Passer domesticus). Journal of Evolutionary Biology, 16(6), 1296-1307. https://doi. org/10.1046/j.1420-9101.2003.00614.x

Jensen, H., Steinsland, I., Ringsby, T. H., \& Sæther, B. E. (2008). Evolutionary dynamics of a sexual ornament in the house sparrow (Passer domesticus): The role of indirect selection within and between sexes. Evolution, 62(6), 1275-1293. https://doi. org/10.1111/j.1558-5646.2008.00395.x

Jin, L., Williamson, A., Banerjee, S., Philipp, I., \& Rape, M. (2008). Mechanism of ubiquitin-chain formation by the human anaphase-promoting complex. Cell, 133(4), 653-665. https://doi. org/10.1016/j.cell.2008.04.012

Joeng, K. S., Song, E. J., Lee, K.-J., \& Lee, J. (2004). Long lifespan in worms with long telomeric DNA. Nature Genetics, 36(6), 607-611. https:// doi.org/10.1038/ng1356 
Jones, A. M., Beggs, A. D., Carvajal-Carmona, L., Farrington, S., Tenesa, A., Walker, M., \& Tomlinson, I. P. M. (2012). TERC polymorphisms are associated both with susceptibility to colorectal cancer and with longer telomeres. Gut, 61(2), 248-254. https://doi.org/10.1136/ gut.2011.239772

Kalinowski, S. T., Taper, M. L., \& Marshall, T. C. (2007). Revising how the computer program CERVUS accommodates genotyping error increases success in paternity assignment. Molecular Ecology, 16(5), 1099-1106. https://doi.org/10.1111/j.1365-294X.2007.03089.x

Kassmann, M., Hansel, A., Leipold, E., Birkenbeil, J., Lu, S.-Q., Hoshi, T., \& Heinemann, S. H. (2008). Oxidation of multiple methionine residues impairs rapid sodium channel inactivation. Pflügers Archiv - European Journal of Physiology, 456(6), 1085-1095. https://doi. org/10.1007/s00424-008-0477-6

Katoh, M. (2009). FGFR2 abnormalities underlie a spectrum of bone, skin, and cancer pathologies. Journal of Investigative Dermatology, 129(8), 1861-1867. https://doi.org/10.1038/jid.2009.97

Kim, S.-Y., Noguera, J. C., Morales, J., \& Velando, A. (2011). Quantitative genetic evidence for trade-off between growth and resistance to oxidative stress in a wild bird. Evolutionary Ecology, 25(2), 461-472. https://doi.org/10.1007/s10682-010-9426-x

Konishi, T., Sasaki, S., Watanabe, T., Kitayama, J., \& Nagawa, H. (2005). Overexpression of hRFI (human ring finger homologous to inhibitor of apoptosis protein type) inhibits death receptor-mediated apoptosis in colorectal cancer cells. Molecular Cancer Therapeutics, 4(5), 743. https://doi.org/10.1158/1535-7163.MCT-05-0020

Kruuk, L. E. B. (2004). Estimating genetic parameters in natural populations using the "animal model". Philosophical Transactions of the Royal Society of London. Series B, Biological Sciences, 359(1446), 873890. https://doi.org/10.1098/rstb.2003.1437

Kruuk, L. E. B., \& Hadfield, J. D. (2007). How to separate genetic and environmental causes of similarity between relatives. Journal of Evolutionary Biology, 20(5), 1890-1903. https://doi. org/10.1111/j.1420-9101.2007.01377.x

Kruuk, L. E. B., Slate, J., \& Wilson, A. J. (2008). New answers for old questions: The evolutionary quantitative genetics of wild animal populations. Annual Review of Ecology, Evolution, and Systematics, 39(1), 525-548. https://doi.org/10.1146/annurev.ecols ys.39.110707.173542

Kvalnes, T., Ringsby, T. H., Jensen, H., Hagen, I. J., Rønning, B., Pärn, H., Holand, H., Engen, S., \& Saether, B.-E. (2017). Reversal of response to artificial selection on body size in a wild passerine. Evolution, 71(8), 2062-2079. https://doi.org/10.1111/evo.13277

Lande, R. (1979). Quantitative genetic analysis of multivariate evolution, applied to brain:body size allometry. Evolution, 33, 402-416. https://doi.org/10.1111/j.1558-5646.1979.tb04694.x

Lande, R., \& Arnold, S. J. (1983). The measurement of selection on correlated characters. Evolution, 37(6), 1210-1226. https://doi. org/10.1111/j.1558-5646.1983.tb00236.x

Lande, R., \& Kirkpatrick, M. (1990). Selection response in traits with maternal inheritance. Genetical Research, 55(3), 189-197. https://doi. org/10.1017/S0016672300025520

Lemaître, J.-F., Pavard, S., Giraudeau, M., Vincze, O., Jennings, G., Hamede, R., Ujvari, B., \& Thomas, F. (2020). Eco-evolutionary perspectives of the dynamic relationships linking senescence and cancer. Functional Ecology, 34(1), 141-152. https://doi.org/10.1111/1365-2435.13394

Levy, D., Neuhausen, S. L., Hunt, S. C., Kimura, M., Hwang, S.-J., Chen, W., Bis, J. C., Fitzpatrick, A. L., Smith, E., Johnson, A. D., Gardner, J. P., Srinivasan, S. R., Schork, N., Rotter, J. I., Herbig, U., Psaty, B. M., Sastrasinh, M., Murray, S. S., Vasan, R. S., ... Aviv, A. (2010). Genome-wide association identifies OBFC1 as a locus involved in human leukocyte telomere biology. Proceedings of the National Academy of Sciences, 107(20), 9293. https://doi.org/10.1073/ pnas.0911494107

Li, C., Stoma, S., Lotta, L. A., Warner, S., Albrecht, E., Allione, A., Arp, P. P., Broer, L., Buxton, J. L., Da Silva Couto Alves, A., Deelen, J., Fedko,
I. O., Gordon, S. D., Jiang, T., Karlsson, R., Kerrison, N., Loe, T. K., Mangino, M., Milaneschi, Y., ... Codd, V. (2020). Genome-wide association analysis in humans links nucleotide metabolism to leukocyte telomere length. The American Journal of Human Genetics, 106(3), 389-404. https://doi.org/10.1016/j.ajhg.2020.02.006

Lieshout, S. H. J., Sparks, A. M., Bretman, A., Newman, C., Buesching, C. D., Burke, T., Macdonald, D. W., \& Dugdale, H. L. (2021). Estimation of environmental, genetic and parental age at conception effects on telomere length in a wild mammal. Journal of Evolutionary Biology, 34(2), 296-308. https://doi.org/10.1111/jeb.13728

Liu, Y., Cao, L., Li, Z., Zhou, D., Liu, W., Shen, Q., Wu, Y., Zhang, D., Hu, X., Wang, T., Ye, J., Weng, X., Zhang, H., Zhang, D. I., Zhang, Z., Liu, F., He, L., \& Shi, Y. (2014). A genome-wide association study identifies a locus on TERT for mean telomere length in Han Chinese. PLoS One, 9(1), e85043. https://doi.org/10.1371/journal.pone.0085043

Lundregan, S. L., Hagen, I. J., Gohli, J., Niskanen, A. K., Kemppainen, P., Ringsby, T. H., Kvalnes, T., Pärn, H., Rønning, B., Holand, H., Ranke, P. S., Båtnes, A. S., Selvik, L.-K., Lien, S., Saether, B.-E., Husby, A., \& Jensen, H. (2018). Inferences of genetic architecture of bill morphology in house sparrow using a high-density SNP array point to a polygenic basis. Molecular Ecology, 27(17), 3498-3514. https://doi. org/10.1111/mec.14811

Mackay, T. F. C., Stone, E. A., \& Ayroles, J. F. (2009). The genetics of quantitative traits: Challenges and prospects. Nature Reviews Genetics, 10(8), 565-577. https://doi.org/10.1038/nrg2612

Mangino, M., Christiansen, L., Stone, R., Hunt, S. C., Horvath, K., Eisenberg, D. T. A., \& Aviv, A. (2015). DCAF4, a novel gene associated with leucocyte telomere length. Journal of Medical Genetics, 52(3), 157-162. https://doi.org/10.1136/jmedgenet-2014-102681

Mangino, M., Hwang, S.-J., Spector, T. D., Hunt, S. C., Kimura, M., Fitzpatrick, A. L., Christiansen, L., Petersen, I., Elbers, C. C., Harris, T., Chen, W., Srinivasan, S. R., Kark, J. D., Benetos, A., El Shamieh, S., Visvikis-Siest, S., Christensen, K., Berenson, G. S., Valdes, A. M., ... Aviv, A. (2012). Genome-wide meta-analysis points to CTC1 and ZNF676 as genes regulating telomere homeostasis in humans. Human Molecular Genetics, 21(24), 5385-5394. https://doi. org $/ 10.1093 / \mathrm{hmg} / \mathrm{dds} 382$

Marasco, V., Boner, W., Griffiths, K., Heidinger, B., \& Monaghan, P. (2019). Intergenerational effects on offspring telomere length: Interactions among maternal age, stress exposure and offspring sex. Proceedings of the Royal Society B: Biological Sciences, 286(1912), 20191845. https://doi.org/10.1098/rspb.2019.1845

Masutomi, K., Yu, E. Y., Khurts, S., Ben-Porath, I., Currier, J. L., Metz, G. B., Brooks, M. W., Kaneko, S., Murakami, S., DeCaprio, J. A., Weinberg, R. A., Stewart, S. A., \& Hahn, W. C. (2003). Telomerase maintains telomere structure in normal human cells. Cell, 114(2), 241-253. https://doi.org/10.1016/S0092-8674(03)00550-6

Mathai, J. C., Mori, S., Smith, B. L., Preston, G. M., Mohandas, N., Collins, M., van Zijl, P. C. M., Zeidel, M. L., \& Agre, P. (1996). Functional analysis of aquaporin-1 deficient red cells. The colton-null phenotype. Journal of Biological Chemistry, 271(3), 1309-1313. https://doi. org/10.1074/jbc.271.3.1309

Matsumoto, R., Fukuoka, H., Iguchi, G., Odake, Y., Yoshida, K., Bando, H., Suda, K., Nishizawa, H., Takahashi, M., Yamada, S., Ogawa, W., \& Takahashi, Y. (2015). Accelerated telomere shortening in acromegaly; IGF-I induces telomere shortening and cellular senescence. PLoS One, 10(10), e0140189. https://doi.org/10.1371/journ al.pone.0140189

McAdam, A. G., Garant, D., \& Wilson, A. J. (2014). The effects of others' genes: Maternal and other indirect genetic effects. In A. Charmantier, D. Garant, \& L. E. B. Kruuk (Eds.), Quantitative genetics in the wild. 1st ed, (pp. 84-103). Oxford University Press.

Merilä, J., \& Sheldon, B. C. (1999). Genetic architecture of fitness and nonfitness traits: Empirical patterns and development of ideas. Heredity, 83(2), 103-109. https://doi. org/10.1046/j.1365-2540.1999.00585.x 
Merilä, J., \& Sheldon, B. C. (2001). Avian quantitative genetics. In V. Nolan, \& C. F. Thompson (Eds.), Current Ornithology (pp. 179-255). Springer US.

Merilä, J., Sheldon, B. C., \& Kruuk, L. E. B. (2001). Explaining stasis: Microevolutionary studies in natural populations. Genetica, 112(1), 199-222. https://doi.org/10.1023/A:1013391806317

Metcalfe, N. B., \& Monaghan, P. (2001). Compensation for a bad start: Grow now, pay later? Trends in Ecology \& Evolution, 16(5), 254-260. https://doi.org/10.1016/S0169-5347(01)02124-3

Metcalfe, N. B., \& Monaghan, P. (2003). Growth versus lifespan: Perspectives from evolutionary ecology. Experimental Gerontology, 38(9), 935-940. https://doi.org/10.1016/S0531-5565(03)00159-1

Mirabello, L., Yu, K., Kraft, P., De Vivo, I., Hunter, D. J., Prescott, J., Wong, J. Y. Y., Chatterjee, N., Hayes, R. B., \& Savage, S. A. (2010). The association of telomere length and genetic variation in telomere biology genesa. Human Mutation, 31(9), 1050-1058. https://doi. org/10.1002/humu.21314

Møller, A. P., Erritzøe, J., \& Soler, J. J. (2017). Life history, immunity, Peto's paradox and tumours in birds. Journal of Evolutionary Biology, 30(5), 960-967. https://doi.org/10.1111/jeb.13060

Monaghan, P. (2010). Telomeres and life histories: The long and the short of it. Annals of the New York Academy of Sciences, 1206, 130-142. https://doi.org/10.1111/j.1749-6632.2010.05705.x

Monaghan, P. (2014). Organismal stress, telomeres and life histories. Journal of Experimental Biology, 217(Pt 1), 57-66. https://doi. org/10.1242/jeb.090043

Monaghan, P., \& Ozanne, S. E. (2018). Somatic growth and telomere dynamics in vertebrates: Relationships, mechanisms and consequences. Philosophical Transactions of the Royal Society of London. Series B, Biological Sciences, 373(1741), 20160446. https://doi. org/10.1098/rstb.2016.0446

Monzani, E., Bazzotti, R., Perego, C., \& La Porta, C. A. M. (2009). AQP1 is not only a water channel: It contributes to cell migration through Lin7/beta-catenin. PLoS One, 4(7), e6167. https://doi.org/10.1371/ journal.pone.0006167

Morrissey, M. B., \& Wilson, A. J. (2010). pedantics: An r package for pedigree-based genetic simulation and pedigree manipulation, characterization and viewing. Molecular Ecology Resources, 10(4), 711-719. https://doi.org/10.1111/j.1755-0998.2009.02817.x

Mousseau, T. A., \& Roff, D. A. (1987). Natural selection and the heritability of fitness components. Heredity, 59(2), 181-197. https://doi. org/10.1038/hdy.1987.113

Müller, R., Jenny, A., \& Stanley, P. (2013). The EGF repeat-specific OGlcNAc-transferase Eogt interacts with notch signaling and pyrimidine metabolism pathways in drosophila. PLoS One, 8(5), e62835. https://doi.org/10.1371/journal.pone.0062835

Mullis, P. E. (2005). Genetic control of growth. European Journal of Endocrinology, 152(1), 11-31. https://doi.org/10.1530/eje.1.01797

Naef-Daenzer, B., \& Keller, L. F. (1999). The foraging performance of great and blue tits (Parus major and P. caeruleus) in relation to caterpillar development, and its consequences for nestling growth and fledging weight. Journal of Animal Ecology, 68(4), 708-718. https:// doi.org/10.1046/j.1365-2656.1999.00318.x

Nassour, J., Radford, R., Correia, A., Fusté, J. M., Schoell, B., Jauch, A. Shaw, R. J., \& Karlseder, J. (2019). Autophagic cell death restricts chromosomal instability during replicative crisis. Nature, 565(7741), 659-663. https://doi.org/10.1038/s41586-019-0885-0

Nawrot, T. S., Staessen, J. A., Gardner, J. P., \& Aviv, A. (2004). Telomere length and possible link to $X$ chromosome. The Lancet, 363(9408), 507-510. https://doi.org/10.1016/S0140-6736(04)15535-9

Nersisyan, L., Nikoghosyan, M., Francioli, L. C., Menelaou, A., Pulit, S. L., \& Elbers, C. C. \& The Genome of the Netherlands Consortium. (2019). WGS-based telomere length analysis in Dutch family trios implicates stronger maternal inheritance and a role for RRM1 gene. Scientific Reports, 9(1), 18758. https://doi.org/10.1038/s41598019-55109-7
Nielsen, S., Frøkiær, J., Marples, D., Kwon, T.-H., Agre, P., \& Knepper, M. A. (2002). Aquaporins in the Kidney: From molecules to medicine. Physiological Reviews, 82(1), 205-244. https://doi.org/10.1152/ physrev.00024.2001

Niskanen, A. K., Billing, A. M., Holand, H., Hagen, I. J., Araya-Ajoy, Y. G., Husby, A., Rønning, B., Myhre, A. M., Ranke, P. S., Kvalnes, T., Pärn, H., Ringsby, T. H., Lien, S., Sæther, B.-E., Muff, S., \& Jensen, $\mathrm{H}$. (2020). Consistent scaling of inbreeding depression in space and time in a house sparrow metapopulation. Proceedings of the National Academy of Sciences, 117(25), 14584. https://doi.org/10.1073/ pnas.1909599117

Njajou, O. T., Cawthon, R. M., Damcott, C. M., Wu, S. H., Ott, S., Garant, M. J., \& Hsueh, W. C. (2007). Telornere length is paternally inherited and is associated with parental lifespan. Proceedings of the National Academy of Sciences of the United States of America, 104(29), 1213512139. https://doi.org/10.1073/pnas.0702703104

Noguera, J. C., da Silva, A., \& Velando, A. (2020). Egg corticosterone can stimulate telomerase activity and promote longer telomeres during embryo development. Molecular Ecology, 00, 1-9. https:// doi.org/10.1111/mec.15694

Noguera José, C., Metcalfe Neil, B., \& Monaghan, P. (2018). Experimental demonstration that offspring fathered by old males have shorter telomeres and reduced lifespans. Proceedings of the Royal Society B: Biological Sciences, 285(1874), 20180268. https://doi.org/10.1098/ rspb.2018.0268

Ojha, J., Codd, V., Nelson, C. P., Samani, N. J., Smirnov, I. V., Madsen, N. R., Hansen, H. M., de Smith, A. J., Bracci, P. M., Wiencke, J. K., Wrensch, M. R., Wiemels, J. L., \& Walsh, K. M. (2016). Genetic variation associated with longer telomere length increases risk of chronic lymphocytic leukemia. Cancer Epidemiology Biomarkers \& Prevention, 25(7), 1043. https://doi.org/10.1158/1055-9965. EPI-15-1329

Oliver, P. L., Finelli, M. J., Edwards, B., Bitoun, E., Butts, D. L., Becker, E. B. E., Cheeseman, M. T., Davies, B., \& Davies, K. E. (2011). Oxr1 is essential for protection against oxidative stress-induced neurodegeneration. PLoS Genetics, 7(10), e1002338. https://doi.org/10.1371/ journal.pgen.1002338

Olsson, M., Pauliny, A., Wapstra, E., Uller, T., Schwartz, T., \& Blomqvist, D. (2011). Sex differences in sand lizard telomere inheritance: Paternal epigenetic effects increases telomere heritability and offspring survival. PLoS One, 6(4), e17473. https://doi.org/10.1371/ journal.pone.0017473

Osaka, F., Kawasaki, H., Aida, N., Saeki, M., Chiba, T., Kawashima, S., \& Kato, S. (1998). A new NEDD8-ligating system for cullin-4A. Genes \& Development, 12(15), 2263-2268. https://doi.org/10.1101/ gad.12.15.2263

Park, J.-I., Venteicher, A. S., Hong, J. Y., Choi, J., Jun, S., Shkreli, M., Chang, W., Meng, Z., Cheung, P., Ji, H., McLaughlin, M., Veenstra, T. D., Nusse, R., McCrea, P. D., \& Artandi, S. E. (2009). Telomerase modulates Wnt signalling by association with target gene chromatin. Nature, 460(7251), 66-72. https://doi.org/10.1038/nature08137

Pauliny, A., Devlin, R. H., Johnsson, J. I., \& Blomqvist, D. (2015). Rapid growth accelerates telomere attrition in a transgenic fish. BMC Evolutionary Biology, 15(1), 159. https://doi.org/10.1186/s1286 2-015-0436-8

Pavlidis, P., Jensen, J. D., Stephan, W., \& Stamatakis, A. (2012). A critical assessment of storytelling: Gene ontology categories and the importance of validating genomic scans. Molecular Biology and Evolution, 29(10), 3237-3248. https://doi.org/10.1093/molbev/mss136

Peig, J., \& Green, A. J. (2010). The paradigm of body condition: A critical reappraisal of current methods based on mass and length. Functional Ecology, 24(6), 1323-1332. https://doi. org/10.1111/j.1365-2435.2010.01751.x

Pepke, M. L., \& Eisenberg, D. T. A. (2020). Accounting for phylogenetic relatedness in cross-species analyses of telomere shortening rates. Experimental Results, 1, e11. https://doi.org/10.1017/exp.2020.18 
Pepke, M. L., \& Eisenberg, D. T. A. (2021). On the comparative biology of mammalian telomeres: Telomere length co-evolves with body mass, lifespan and cancer risk. Molecular Ecology, https://doi. org/10.1111/mec.15870

Pepke, M. L., Kvalnes, T., Rønning, B., Jensen, H., Boner, W., Sæther, B.E., Monaghan, P. \& Ringsby, T. H. (2021). Artificial size selection experiment reveals telomere length dynamics and fitness consequences in a wild passerine. Authorea. https://doi.org/10.22541/ au.161447476.67562312/v1

Perry, E., Tsruya, R., Levitsky, P., Pomp, O. Z., Taller, M., Weisberg, S., Parris, W., Kulkarni, S., Malovani, H., Pawson, T., Shpungin, S., \& Nir, U. (2004). TMF/ARA160 is a BC-box-containing protein that mediates the degradation of Stat3. Oncogene, 23(55), 8908-8919. https://doi.org/10.1038/sj.onc.1208149

Pesavento, P. A., Agnew, D., Keel, M. K., \& Woolard, K. D. (2018). Cancer in wildlife: Patterns of emergence. Nature Reviews Cancer, 18(10), 646-661. https://doi.org/10.1038/s41568-018-0045-0

Peuscher, M. H., \& Jacobs, J. J. L. (2012). Posttranslational control of telomere maintenance and the telomere damage response. Cell Cycle, 11(8), 1524-1534. https://doi.org/10.4161/cc.19847

Pierini, D., \& Bryan, N. S. (2015). Nitric oxide availability as a marker of oxidative stress. Methods in Molecular Biology, 1208, 63-71. https:// doi.org/10.1007/978-1-4939-1441-8_5

Plummer, M., Best, N., Cowles, K., \& Vines, K. (2006). CODA: Convergence diagnosis and output analysis for MCMC. R News, 6(1), 7-11.

Potti, J., \& Merino, S. (1994). Heritability estimates and maternal effects on tarsus length in pied flycatchers, Ficedula hypoleuca. Oecologia, 100(3), 331-338. https://doi.org/10.1007/BF00316962

Prescott, J., Kraft, P., Chasman, D. I., Savage, S. A., Mirabello, L., Berndt, S. I., Weissfeld, J. L., Han, J., Hayes, R. B., Chanock, S. J., Hunter, D. J., \& De Vivo, I. (2011). Genome-wide association study of relative telomere length. PLoS One, 6(5), e19635. https://doi.org/10.1371/ journal.pone.0019635

R Core Team. (2020). R: A language and environment for statistical computing. (Version 3.6.3). R Foundation for Statistical Computing. www.Rproject.org/

Radi, R. (2018). Oxygen radicals, nitric oxide, and peroxynitrite: Redox pathways in molecular medicine. Proceedings of the National Academy of Sciences, 115(23), 5839. https://doi.org/10.1073/ pnas.1804932115

Räsänen, K., \& Kruuk, L. E. B. (2007). Maternal effects and evolution at ecological time-scales. Functional Ecology, 21(3), 408-421. https:// doi.org/10.1111/j.1365-2435.2007.01246.x

Reichert, S., Rojas, E. R., Zahn, S., Robin, J. P., Criscuolo, F., \& Massemin, S. (2015). Maternal telomere length inheritance in the king penguin. Heredity, 114(1), 10-16. https://doi.org/10.1038/hdy.2014.60

Reichert, S., \& Stier, A. (2017). Does oxidative stress shorten telomeres in vivo? A Review. Biology Letters, 13(12), 20170463. https://doi. org/10.1098/rsbl.2017.0463

Reid, J. M., \& Keller, L. F. (2010). Correlated inbreeding among relatives: Occurrence, magnitude, and implications. Evolution, 64(4), 973985. https://doi.org/10.1111/j.1558-5646.2009.00865.x

Remot, F., Ronget, V., Froy, H., Rey, B., Gaillard, J.-M., Nussey, D. H., \& Lemaître, J.-F. (2021). Decline in telomere length with increasing age across non-human vertebrates: A meta-analysis. Molecular Ecology, 00, 1-16. https://doi.org/10.1111/mec.16145

Ringsby, T. H., Berge, T., Sæther, B.-E., \& Jensen, H. (2009). Reproductive success and individual variation in feeding frequency of House Sparrows (Passer domesticus). Journal of Ornithology, 150(2), 469481. https://doi.org/10.1007/s10336-008-0365-z

Ringsby, T. H., Jensen, H., Pärn, H., Kvalnes, T., Boner, W., Gillespie, R., Holand, H., Hagen, I. J., Rønning, B., Sæther, B.-E., \& Monaghan, P. (2015). On being the right size: Increased body size is associated with reduced telomere length under natural conditions. Proceedings of the Royal Society B: Biological Sciences, 282(1820), 20152331. https://doi.org/10.1098/rspb.2015.2331
Ringsby, T. H., Sæther, B.-E., \& Solberg, E. J. (1998). Factors affecting juvenile survival in house sparrow Passer domesticus. Journal of Avian Biology, 29(3), 241-247. https://doi.org/10.2307/3677106

Ringsby, T. H., Sæther, B.-E., Tufto, J., Jensen, H., \& Solberg, E. J. (2002). Asynchronous spatiotemporal demography of a house sparrow metapopulation in a correlated environment. Ecology, 83(2), 561569. https://doi.org/10.1890/0012-9658(2002)0830561:Asdoa h2.0.Co;2

Roff, D. A. (1995). The estimation of genetic correlations from phenotypic correlations: A test of Cheverud's conjecture. Heredity, 74(5), 481-490. https://doi.org/10.1038/hdy.1995.68

Roff, D. A. (2012). Evolutionary quantitative genetics. Springer Science \& Business Media.

Roff, D. A., \& Fairbairn, D. J. (2012). A test of the hypothesis that correlational selection generates genetic correlations. Evolution, 66(9), 2953-2960. https://doi.org/10.1111/j.1558-5646.2012.01656.x

Rollings, N., Uhrig, E. J., Krohmer, R. W., Waye, H. L., Mason, R. T., Olsson, M., Whittington, C. M., \& Friesen, C. R. (2017). Age-related sex differences in body condition and telomere dynamics of red-sided garter snakes. Proceedings of the Royal Society B: Biological Sciences, 284(1852), 20162146. https://doi.org/10.1098/rspb.2016.2146

Rönnegård, L., McFarlane, S. E., Husby, A., Kawakami, T., Ellegren, H., \& Qvarnström, A. (2016). Increasing the power of genome wide association studies in natural populations using repeated measures - Evaluation and implementation. Methods in Ecology and Evolution, 7(7), 792-799. https://doi.org/10.1111/2041-210X.12535

Rønning, B., Broggi, J., Bech, C., Moe, B., Ringsby, T. H., Pärn, H., Hagen, I. J., Sæther, B.-E., \& Jensen, H. (2016). Is basal metabolic rate associated with recruit production and survival in free-living house sparrows? Functional Ecology,30(7), 1140-1148. https://doi. org/10.1111/1365-2435.12597

Saadoun, S., Papadopoulos, M. C., Hara-Chikuma, M., \& Verkman, A. S. (2005). Impairment of angiogenesis and cell migration by targeted aquaporin-1 gene disruption. Nature, 434(7034), 786-792. https:// doi.org/10.1038/nature03460

Saeed, H., \& Iqtedar, M. (2015). Aberrant gene expression profiles, during in vitro osteoblast differentiation, of telomerase deficient mouse bone marrow stromal stem cells (mBMSCs). Journal of Biomedical Science, 22(1), 11. https://doi.org/10.1186/s12929-015-0116-4

Salmón, P., Millet, C., Selman, C., \& Monaghan, P. (2021). Growth acceleration results in faster telomere shortening later in life. Proceedings of the Royal Society B: Biological Sciences, 288(1956), 20211118. https://doi.org/10.1098/rspb.2021.1118

Sasaki, S., Nakamura, T., Arakawa, H., Mori, M., Watanabe, T., Nagawa, H., \& Croce, C. M. (2002). Isolation and characterization of a novel gene, hRFI, preferentially expressed in esophageal cancer. Oncogene, 21(32), 5024-5030. https://doi.org/10.1038/sj.onc.1205627

Schally, A. V., Wang, H., He, J., Cai, R., Sha, W., Popovics, P., Perez, R., Vidaurre, I., \& Zhang, X. (2018). Agonists of growth hormonereleasing hormone $(\mathrm{GHRH})$ inhibit human experimental cancers in vivo by down-regulating receptors for GHRH. Proceedings of the National Academy of Sciences of the United States of America, 115(47), 12028-12033. https://doi.org/10.1073/pnas.1813375115

Schmandt, R., Liu, S. K., \& McGlade, C. J. (1999). Cloning and characterization of mPAL, a novel Shc SH2 domain-binding protein expressed in proliferating cells. Oncogene, 18(10), 1867-1879. https://doi. org/10.1038/sj.onc.1202507

Schulte-Hostedde, A. I., Zinner, B., Millar, J. S., \& Hickling, G. J. (2005). Restitution of mass-size residuals: Validating body condition indices. Ecology, 86(1), 155-163. https://doi.org/10.1890/04-0232

Seeker, L. A., Ilska, J. J., Psifidi, A., Wilbourn, R. V., Underwood, S. L., Fairlie, J., Holland, R., Froy, H., Salvo-Chirnside, E., Bagnall, A., Whitelaw, B., Coffey, M. P., Nussey, D. H., \& Banos, G. (2018). Bovine telomere dynamics and the association between telomere length and productive lifespan. Scientific Reports, 8(1), 12748. https://doi.org/10.1038/s41598-018-31185-z 
Senar, J., \& Pascual, J. (1997). Keel and tarsus length may provide a good predictor of avian body size. Ardea, 85, 269-274.

Slate, J. (2013). From beavis to beak color: A simulation study to examine how much qtl mapping can reveal about the genetic architecture of quantitative traits. Evolution, 67(5), 1251-1262. https://doi. org/10.1111/evo.12060

Smith, S. M., Nager, R. G., \& Costantini, D. (2016). Meta-analysis indicates that oxidative stress is both a constraint on and a cost of growth Ecology and Evolution, 6(9), 2833-2842. https://doi.org/10.1002/ ece3.2080

Soerensen, M., Dato, S., Tan, Q., Thinggaard, M., Kleindorp, R., Beekman, M., Jacobsen, R., Suchiman, H. E. D., de Craen, A. J. M., Westendorp, R. G. J., Schreiber, S., Stevnsner, T., Bohr, V. A., Slagboom, P. E., Nebel, A., Vaupel, J. W., Christensen, K., McGue, M., \& Christiansen, L. (2012). Human longevity and variation in GH/IGF-1/insulin signaling, DNA damage signaling and repair and pro/antioxidant pathway genes: Cross sectional and longitudinal studies. Experimental Gerontology, 47(5), 379-387. https://doi. org/10.1016/j.exger.2012.02.010

Sparks, A. M., Spurgin, L. G., Velde, M., Fairfield, E. A., Komdeur, J., Burke, T., Richardson, D. S., \& Dugdale, H. L. (2021). Telomere heritability and parental age at conception effects in a wild avian population. Molecular Ecology, https://doi.org/10.1111/mec.15804

Spurgin, L. G., Bebbington, K., Fairfield, E. A., Hammers, M., Komdeur, J., Burke, T., Dugdale, H. L., \& Richardson, D. S. (2018). Spatiotemporal variation in lifelong telomere dynamics in a long-term ecological study. Journal of Animal Ecology, 87(1), 187-198. https:// doi.org/10.1111/1365-2656.12741

Stier, A., Hsu, B.-Y., Marciau, C., Doligez, B., Gustafsson, L., Bize, P., \& Ruuskanen, S. (2020). Born to be young? Prenatal thyroid hormones increase early-life telomere length in wild collared flycatchers. Biology Letters, 16(11), 20200364. https://doi.org/10.1098/ rsbl.2020.0364

Stier, A., Metcalfe, N. B., \& Monaghan, P. (2020). Pace and stability of embryonic development affect telomere dynamics: An experimental study in a precocial bird model. Proceedings of the Royal Society B: Biological Sciences, 287(1933), 20201378. https://doi.org/10.1098/ rspb.2020.1378

Sudyka, J. (2019). Does reproduction shorten telomeres? Towards integrating individual quality with life-history strategies in telomere biology. BioEssays, 41(11), e1900095. https://doi.org/10.1002/ bies.201900095

Tacutu, R., Budovsky, A., Yanai, H., \& Fraifeld, V. E. (2011). Molecular links between cellular senescence, longevity and age-related diseases - A systems biology perspective. Aging, 3(12), 1178-1191. https://doi.org/10.18632/aging.100413

Tamma, G., Valenti, G., Grossini, E., Donnini, S., Marino, A., Marinelli, R. A., \& Calamita, G. (2018). Aquaporin membrane channels in oxidative stress, cell signaling, and aging: Recent advances and research trends. Oxidative Medicine and Cellular Longevity, 2018, 1501847. https://doi.org/10.1155/2018/1501847

Tao, H. C., Wang, H. X., Dai, M., Gu, C. Y., Wang, Q., Han, Z. G., \& Cai, B. (2013). Targeting SHCBP1 inhibits cell proliferation in human hepatocellular carcinoma cells. Asian Pacific Journal of Cancer Prevention, 14(10), 5645-5650. https://doi.org/10.7314/ apjcp.2013.14.10.5645

Thomas, F., Vavre, F., Tissot, T., Vittecoq, M., Giraudeau, M., Bernex, F., Misse, D., Renaud, F., Raven, N., Beckmann, C., Hamede, R., Biro, P. A., \& Ujvari, B. (2018). Cancer is not (only) a senescence problem. Trends in Cancer, 4(3), 169-172. https://doi.org/10.1016/j. trecan.2018.01.002

Tian, X., Doerig, K., Park, R., Can Ran Qin, A., Hwang, C., Neary, A., Gilbert, M., Seluanov, A., \& Gorbunova, V. (2018). Evolution of telomere maintenance and tumour suppressor mechanisms across mammals. Philosophical Transactions of the Royal Society of London.
Series B, Biological Sciences, 373(1741), 20160443. https://doi. org/10.1098/rstb.2016.0443

Tomita, Y., Dorward, H., Yool, A. J., Smith, E., Townsend, A. R., Price, T. J., \& Hardingham, J. E. (2017). Role of aquaporin 1 signalling in cancer development and progression. International Journal of Molecular Sciences, 18(2), 299. https://doi.org/10.3390/ijms18020299

Tricola, G. M., Simons, M. J. P., Atema, E., Boughton, R. K., Brown, J. L., Dearborn, D. C., Divoky, G., Eimes, J. A., Huntington, C. E., Kitaysky, A. S., Juola, F. A., Lank, D. B., Litwa, H. P., Mulder, E. G. A., Nisbet, I. C. T., Okanoya, K., Safran, R. J., Schoech, S. J., Schreiber, E. A., ... Haussmann, M. F. (2018). The rate of telomere loss is related to maximum lifespan in birds. Philosophical Transactions of the Royal Society B: Biological Sciences, 373(1741), 20160445. https:// doi.org/10.1098/rstb.2016.0445

Tsujino, A., Maertens, C., Ohno, K., Shen, X.-M., Fukuda, T., Harper, C. M., Cannon, S. C., \& Engel, A. G. (2003). Myasthenic syndrome caused by mutation of the SCN4A sodium channel. Proceedings of the National Academy of Sciences, 100(12), 7377. https://doi. org/10.1073/pnas.1230273100

van de Pol, M., \& Wright, J. (2009). A simple method for distinguishing within-versus between-subject effects using mixed models. Animal Behaviour, 77(3), 753. https://doi.org/10.1016/j.anbeh av.2008.11.006

van Gool, S. A., Kamp, G. A., Odink, R. J., de Muinck Keizer-Schrama, S. M., Delemarre-van de Waal, H. A., Oostdijk, W., \& Wit, J. M. (2010). High-dose GH treatment limited to the prepubertal period in young children with idiopathic short stature does not increase adult height. European Journal of Endocrinology, 162(4), 653-660. https://doi.org/10.1530/eje-09-0880

VanderKuur, J. A., Wang, X., Zhang, L., Campbell, G. S., Allevato, G., Billestrup, N., Norstedt, G., \& Carter-Su, C. (1994). Domains of the growth hormone receptor required for association and activation of JAK2 tyrosine kinase. Journal of Biological Chemistry, 269(34), 21709-21717. https://doi.org/10.1016/S0021-9258(17)31863-X

Vargas-Ayala, R. C., Jay, A., Manara, F., Maroui, M. A., Hernandez-Vargas, H., Diederichs, A., Robitaille, A., Sirand, C., Ceraolo, M. G., RomeroMedina, M. C., Cros, M. P., Cuenin, C., Durand, G., Le Calvez-Kelm, F., Mundo, L., Leoncini, L., Manet, E., Herceg, Z., Gruffat, H., \& Accardi, R. (2019). Interplay between the epigenetic enzyme lysine (K)-specific demethylase $2 \mathrm{~B}$ and Epstein-Barr virus infection. Journal of Virology, 93(13), e00273-e1219. https://doi.org/10.1128/ JVI.00273-19

Vasa, M., Breitschopf, K., Zeiher Andreas, M., \& Dimmeler, S. (2000). Nitric oxide activates telomerase and delays endothelial cell senescence. Circulation Research, 87(7), 540-542. https://doi. org/10.1161/01.RES.87.7.540

Vasa-Nicotera, M., Brouilette, S., Mangino, M., Thompson, J. R., Braund, P., Clemitson, J.-R., Mason, A., Bodycote, C. L., Raleigh, S. M., Louis, E., \& Samani, N. J. (2005). Mapping of a major locus that determines telomere length in humans. The American Journal of Human Genetics, 76(1), 147-151. https://doi.org/10.1086/426734

Vedder, O., Moiron, M., Bichet, C., Bauch, C., Verhulst, S., Becker, P. H., $\&$ Bouwhuis, S. (2021). Telomere length is heritable and genetically correlated with lifespan in a wild bird. Molecular Ecology, 00, 1-11. https://doi.org/10.1111/mec.15807

Verkman, A. S., Anderson, M. O., \& Papadopoulos, M. C. (2014). Aquaporins: Important but elusive drug targets. Nature Reviews Drug Discovery, 13(4), 259-277. https://doi.org/10.1038/nrd4226

Verkman, A. S., Hara-Chikuma, M., \& Papadopoulos, M. C. (2008). Aquaporins - New players in cancer biology. Journal of Molecular Medicine (Berlin, Germany), 86(5), 523-529. https://doi.org/10.1007/ s00109-008-0303-9

Viblanc, V. A., Schull, Q., Stier, A., Durand, L., Lefol, E., Robin, J.-P., Zahn, S., Bize, P., \& Criscuolo, F. (2020). Foster rather than biological parental telomere length predicts offspring survival and telomere 
length in king penguins. Molecular Ecology, 29(16), 3155-3167. https://doi.org/10.1111/mec.15485

Villanova, T., Gesmundo, I., Audrito, V., Vitale, N., Silvagno, F., Musuraca, C., Righi, L., Libener, R., Riganti, C., Bironzo, P., Deaglio, S., Papotti, M., Cai, R., Sha, W., Ghigo, E., Schally, A. V., \& Granata, R. (2019). Antagonists of growth hormone-releasing hormone (GHRH) inhibit the growth of human malignant pleural mesothelioma. Proceedings of the National Academy of Sciences of the United States of America, 116(6), 2226-2231. https://doi.org/10.1073/pnas.1818865116

Visscher, P. M., Hill, W. G., \& Wray, N. R. (2008). Heritability in the genomics era - Concepts and misconceptions. Nature Reviews Genetics, 9(4), 255-266. https://doi.org/10.1038/nrg2322

Voillemot, M., Hine, K., Zahn, S., Criscuolo, F., Gustafsson, L., Doligez, B., \& Bize, P. (2012). Effects of brood size manipulation and common origin on phenotype and telomere length in nestling collared flycatchers. BMC Ecology, 12(1), 17. https://doi. org/10.1186/1472-6785-12-17

Volkert, M. R., Elliott, N. A., \& Housman, D. E. (2000). Functional genomics reveals a family of eukaryotic oxidation protection genes. Proceedings of the National Academy of Sciences of the United States of America, 97(26), 14530-14535. https://doi.org/10.1073/ pnas. 260495897

von Zglinicki, T. (2002). Oxidative stress shortens telomeres. Trends in Biochemical Sciences, 27(7), 339-344. https://doi.org/10.1016/ S0968-0004(02)02110-2

Wang, H., Zhang, K., Liu, Y., Fu, Y., Gao, S., Gong, P., Wang, H., Zhou, Z., Zeng, M., Wu, Z., Sun, Y. U., Chen, T., Li, S., \& Liu, L. (2017). Telomere heterogeneity linked to metabolism and pluripotency state revealed by simultaneous analysis of telomere length and RNA-seq in the same human embryonic stem cell. BMC Biology, 15(1), 114. https://doi.org/10.1186/s12915-017-0453-8

Wang, L., Zhu, G., Yang, D., Li, Q., Li, Y., Xu, X., He, D., \& Zeng, C. (2008). The spindle function of CDCA4. Cell Motil Cytoskeleton, 65(7), 581593. https://doi.org/10.1002/cm.20286

Wellmann, R. (2021). optiSel: Optimum contribution selection and population genetics. R package version 2.0.5. https://CRAN.R-proje ct.org $/$ package $=$ optiSel

Weng, Q., Du, J., Yu, F., Huang, T., Chen, M., Lv, H., Ma, H., Hu, Z., Jin, G., Hu, Y., \& Shen, H. (2016). The known genetic loci for telomere length may be involved in the modification of telomeres length after birth. Scientific Reports, 6(1), 38729. https://doi.org/10.1038/ srep38729

Wilbourn, R. V., Moatt, J. P., Froy, H., Walling, C. A., Nussey, D. H., \& Boonekamp, J. J. (2018). The relationship between telomere length and mortality risk in non-model vertebrate systems: A metaanalysis. Philosophical Transactions of the Royal Society of London. Series B, Biological Sciences, 373(1741), 20160447. https://doi. org/10.1098/rstb.2016.0447

Wilson, A. J. (2008). Why h2 does not always equal VA/VP? Journal of Evolutionary Biology, 21(3), 647-650. https://doi. org/10.1111/j.1420-9101.2008.01500.x

Wilson, A. J., Coltman, D. W., Pemberton, J. M., Overall, A. D. J., Byrne, K. A., \& Kruuk, L. E. B. (2005). Maternal genetic effects set the potential for evolution in a free-living vertebrate population. Journal of Evolutionary Biology, 18(2), 405-414. https://doi. org/10.1111/j.1420-9101.2004.00824.x

Wilson, A. J., Réale, D., Clements, M. N., Morrissey, M. M., Postma, E., Walling, C. A., Kruuk, L. E. B., \& Nussey, D. H. (2010). An ecologist's guide to the animal model. Journal of Animal Ecology, 79(1), 13-26. https://doi.org/10.1111/j.1365-2656.2009.01639.x

Wolf, J. B., Brodie lii, E. D., Cheverud, J. M., Moore, A. J., \& Wade, M. J. (1998). Evolutionary consequences of indirect genetic effects. Trends in Ecology \& Evolution, 13(2), 64-69. https://doi.org/10.1016/ S0169-5347(97)01233-0

Wolf, J. B., \& Wade, M. J. (2016). Evolutionary genetics of maternal effects. Evolution, 70(4), 827-839. https://doi.org/10.1111/evo.12905
Wood, E. M., \& Young, A. J. (2019). Telomere attrition predicts reduced survival in a wild social bird, but short telomeres do not. Molecular Ecology, 28(16), 3669-3680. https://doi.org/10.1111/mec.15181

Xu, Y., Wu, X., Li, F., Huang, D., \& Zhu, W. (2018). CDCA4, a downstream gene of the Nrf2 signaling pathway, regulates cell proliferation and apoptosis in the MCF-7/ADM human breast cancer cell line. Molecular Medicine Reports, 17(1), 1507-1512. https://doi. org/10.3892/mmr.2017.8095

Yalçin, Z., Selenz, C., \& Jacobs, J. J. L. (2017). Ubiquitination and SUMOylation in telomere maintenance and dysfunction. Frontiers in Genetics, 8, 67. https://doi.org/10.3389/fgene.2017.00067

Yamazato, Y., Shiozaki, A., Ichikawa, D., Kosuga, T., Shoda, K., Arita, T., Konishi, H., Komatsu, S., Kubota, T., Fujiwara, H., Okamoto, K., Kishimoto, M., Konishi, E., Marunaka, Y., \& Otsuji, E. (2018). Aquaporin 1 suppresses apoptosis and affects prognosis in esophageal squamous cell carcinoma. Oncotarget, 9(52), 29957-29974. https://doi.org/10.18632/oncotarget.25722

Yang, M., Lin, X., Rowe, A., Rognes, T., Eide, L., \& Bjørås, M. (2015). Transcriptome analysis of human OXR1 depleted cells reveals its role in regulating the p53 signaling pathway. Scientific Reports, 5(1), 17409. https://doi.org/10.1038/srep17409

Yeh, Y.-M., Pan, Y.-T., \& Wang, T.-C.-V. (2005). Cdc42/Rac1 participates in the control of telomerase activity in human nasopharyngeal cancer cells. Cancer Letters, 218(2), 207-213. https://doi.org/10.1016/j. canlet.2004.06.047

Young, A. J. (2018). The role of telomeres in the mechanisms and evolution of life-history trade-offs and ageing. Philosophical Transactions of the Royal Society of London. Series B, Biological Sciences, 373(1741), 20160452. https://doi.org/10.1098/rstb.2016.0452

Yuen, M., Sandaradura, S. A., Dowling, J. J., Kostyukova, A. S., Moroz, N., Quinlan, K. G., Lehtokari, V.-L., Ravenscroft, G., Todd, E. J., Ceyhan-Birsoy, O., Gokhin, D. S., Maluenda, J., Lek, M., Nolent, F., Pappas, C. T., Novak, S. M., D'Amico, A., Malfatti, E., Thomas, B. P., ... Clarke, N. F. (2014). Leiomodin-3 dysfunction results in thin filament disorganization and nemaline myopathy. The Journal of Clinical Investigation, 124(11), 4693-4708. https://doi.org/10.1172/ JCI75199

Zeiger, A. M., White, M. J., Eng, C., Oh, S. S., Witonsky, J., Goddard, P. C., Contreras, M. G., Elhawary, J. R., Hu, D., Mak, A. C. Y., Lee, E. Y., Keys, K. L., Samedy, L.-A., Risse-Adams, O., Magaña, J., Huntsman, S., Salazar, S., Davis, A., Meade, K., ... Burchard, E. G. (2018). Genetic determinants of telomere length in African American youth. Scientific Reports, 8(1), 13265. https://doi.org/10.1038/ s41598-018-31238-3

Zhang, R., Zhao, J., Song, Y., Wang, X. U., Wang, L., Xu, J., Song, C., \& Liu, F. (2014). The E3 ligase RNF34 is a novel negative regulator of the NOD1 pathway. Cellular Physiology and Biochemistry, 33(6), 19541962. https://doi.org/10.1159/000362972

Zhang, X., Zhang, S., Liu, X., Wang, Y., Chang, J., Zhang, X., Mackintosh, S. G., Tackett, A. J., He, Y., Lv, D., Laberge, R.-M., Campisi, J., Wang, J., Zheng, G., \& Zhou, D. (2018). Oxidation resistance 1 is a novel senolytic target. Aging Cell, 17(4), e12780. https://doi.org/10.1111/ acel.12780

Zhang, Z.-B., Zhang, L., Shang, X.-J., Li, H.-F., Shi, Y.-Q., Li, W., Teves, M. E., Wang, Z.-Q., Jiang, G.-F., \& Song, S.-Z. (2015). Characterization of membrane occupation and recognition nexus repeat containing 3, meiosis expressed gene 1 binding partner, in mouse male germ cells. Asian Journal of Andrology, 17(1), 86-93. https://doi. org/10.4103/1008-682x.138186

Zhou, J., Ye, J., Zhao, X., Li, A., \& Zhou, J. (2008). JWA is required for arsenic trioxide induced apoptosis in HeLa and MCF-7 cells via reactive oxygen species and mitochondria linked signal pathway. Toxicology and Applied Pharmacology, 230(1), 33-40. https://doi. org/10.1016/j.taap.2008.01.041

Zou, A., Wu, A., Luo, M., Zhou, C., Lu, Y., \& Yu, X. (2019). SHCBP1 promotes cisplatin induced apoptosis resistance, migration and 
invasion through activating Wnt pathway. Life Sciences, 235 116798. https://doi.org/10.1016/j.lfs.2019.116798

\section{SUPPORTING INFORMATION}

Additional supporting information may be found in the online version of the article at the publisher's website.
How to cite this article: Pepke, M. L., Kvalnes, T., Lundregan, S., Boner, W., Monaghan, P., Sæther, B.-E., Jensen, H., \& Ringsby, T. H. (2022). Genetic architecture and heritability of early-life telomere length in a wild passerine. Molecular Ecology, 31, 6360-6381. https://doi.org/10.1111/mec.16288 